\title{
WATER WITHDRAWAL AND USE IN MARYLAND, 1990-91
}

By Judith C. Wheeler

\section{U.S. GEOLOGICAL SURVEY}

Water-Resources Investigations Report 93-4225

Prepared in cooperation with the

MARYLAND WATER RESOURCES ADMINISTRATION and the MARYLAND GEOLOGICAL SURVEY

Towson, Maryland

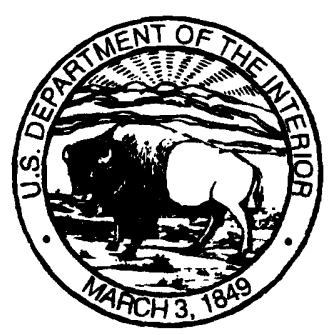

1995 


\section{U.S. DEPARTMENT OF THE INTERIOR \\ BRUCE BABBITT, Secretary \\ U.S. GEOLOGICAL SURVEY}

Gordon P. Eaton, Director

For additional information write to:

Copies of this report can be purchased from:

District Chief

U.S. Geological Survey, WRD

208 Carroll Building

8600 La Salle Road

Towson, Maryland 21286
U.S. Geological Survey

Earth Science Information Center

Open-File Reports Section

Box 25286, MS 517

Denver Federal Center

Denver CO 80225 


\section{CONTENTS}

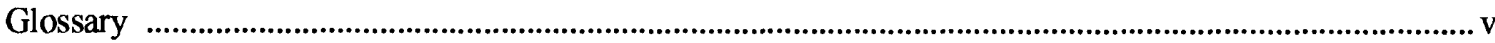

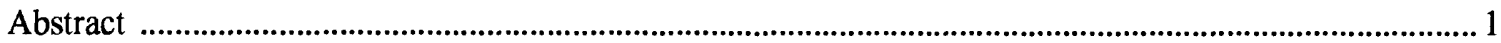

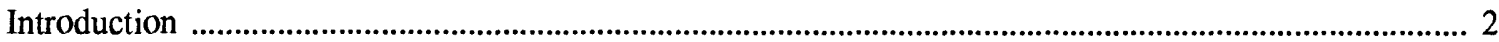

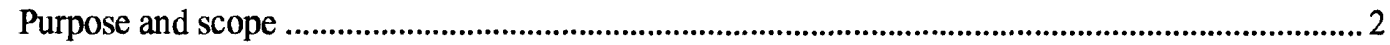

Methods of data collection and estimation

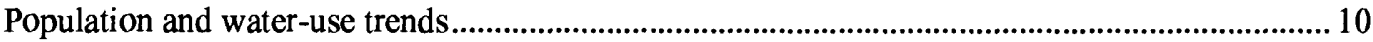

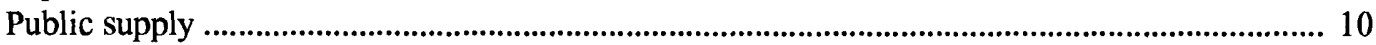

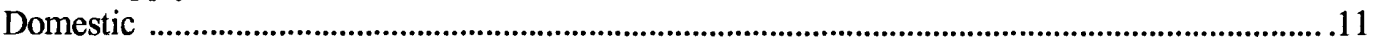

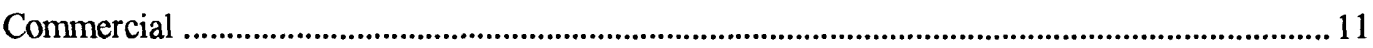

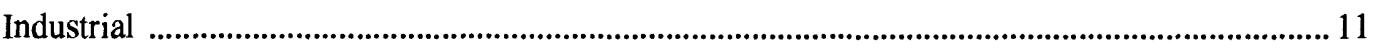

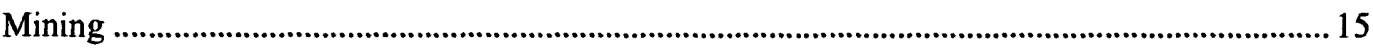

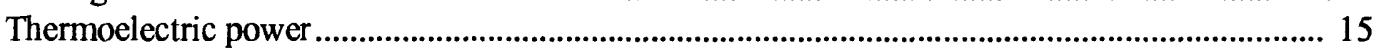

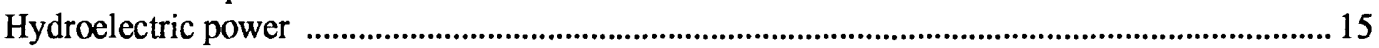

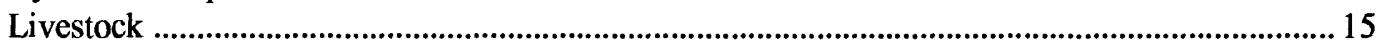

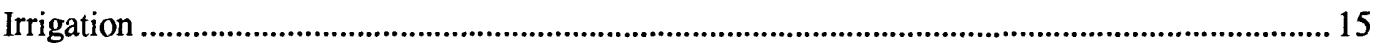

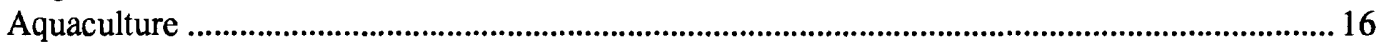

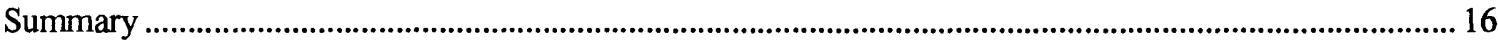

Selected references ............................................................................................................................... 18

Appendix: Water withdrawal and use data for Maryland, 1990-91 ......................................................... 21

\section{FIGURES}

1. Map showing the counties of Maryland and selected adjacent counties of Virginia, West Virginia, and Pennsylvania..................................................................................................... 3

2. Map showing freshwater withdrawals in Maryland, by county, $1990-91$................................. 6

3. Bar charts showing freshwater withdrawals and source of water in Maryland, by category of use, 1990-91 ...................................................................................... 7

4. Maps showing fresh surface-water and ground-water withdrawals in

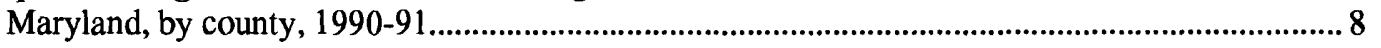

5. Map and bar charts showing fresh surface-water and ground-water withdrawals in Maryland, by principal drainage basin, 1990-91 ...................................................9

6. Maps and bar chart showing ground-water withdrawals in Maryland, by principal aquifers, 1990-91 .................................................................................. 12

7. Graph showing population and freshwater withdrawals in Maryland, 1950-91 ................. 14

\section{TABLES}

1. Maryland water suppliers cross-boundary withdrawals and deliveries, 1990-91 ...............................5

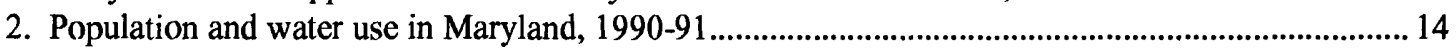

3. Total water withdrawals (excluding hydroelectric power) in Maryland, by county
a. 1990

b. 1991 .

4. Public-supply water withdrawals and deliveries in Maryland, by county
a. 1990 24
b. 1991 . 


\section{TABLES-- (Continued)}

5. Domestic water withdrawals (self-supplied) and deliveries from public suppliers in Maryland, by county:

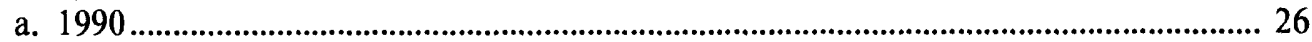

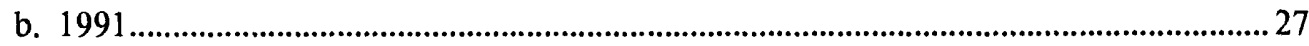

6. Commercial freshwater withdrawals (self-supplied) and deliveries from public suppliers in Maryland, by county:

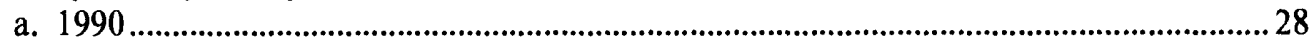

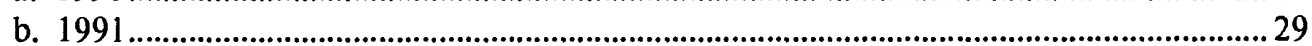

7. Industrial water withdrawals (self-supplied) and deliveries from public suppliers in

Maryland, by county:

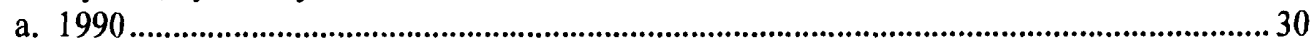

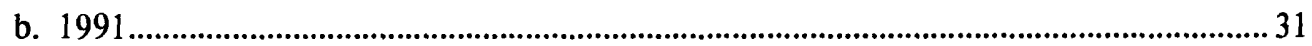

8. Mining water withdrawals in Maryland, by county:

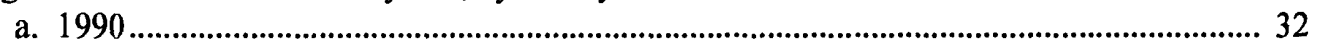

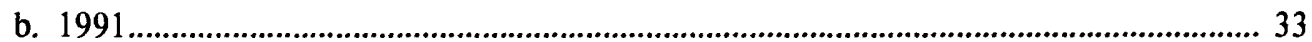

9. Thermoelectric power water withdrawals in Maryland, by county:

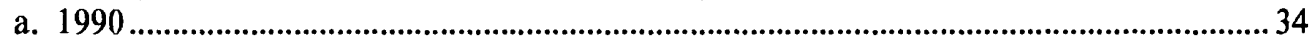

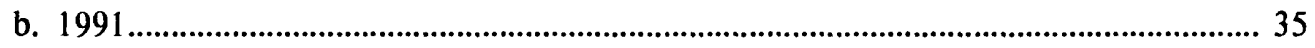

10. Hydroelectric power water use in Maryland, by county:

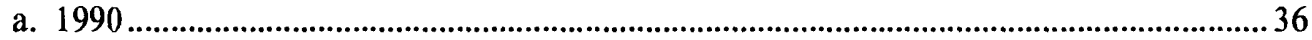

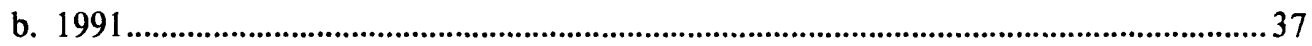

11. Livestock water withdrawals in Maryland, by county, 1990-91 ................................................... 38

12. Irrigation water withdrawals in Maryland, by county:

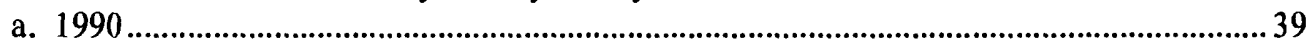

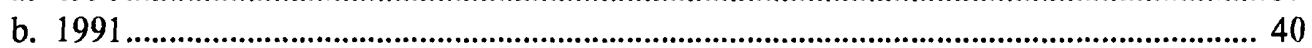

13. Aquaculture water withdrawals in Maryland, by county:

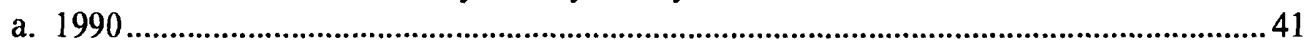

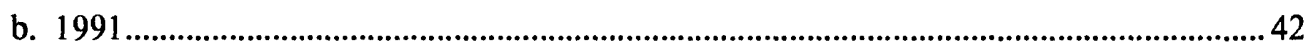


[Definitions modified from Solley and others, 1988; Maryland Water Resources Administration, 1987; and Drever, 1982]

Agriculture (nonirrigation) water use.-- Water used for livestock watering, feedlots, dairy operations, and other farm needs. Livestock includes cattle, dairy cows, sheep, hogs, and poultry.

Aquaculture.- The controlled production of finfish, shellfish, and aquatic plants in fresh and saline water; also called fish farming or fish culture.

Aquifer.- A rock unit (including unconsolidated sediments) that will yield water in a usable quantity to wells or springs.

Brackish water.- Water that is too saline to be potable, but is significantly less saline than seawater. Total dissolved solids (TDS) concentration in brackish water ranges from 1,000 to $20,000 \mathrm{mg} / \mathrm{L}$ (milligrams per liter), whereas TDS concentration in seawater is about $35,000 \mathrm{mg} / \mathrm{L}$.

Commercial water use.-- Water withdrawn for motels, hotels, restaurants, office buildings, and other commercial facilities, and for educational, civilian, and military institutions. Laboratories and research facilities are also included in this category. Water can be obtained from a public supply or can be self-supplied.

Consumptive use (consumed water) .- That quantity of water withdrawn that is evaporated, transpired, incorporated into products or absorbed by crops, consumed by humans or livestock, or otherwise removed from the immediate water environment.

Cooling water.-- Water used to cool condensers, nuclear reactors, and other commercial and industrial equipment.

Domestic water use .- Water that is obtained from a public supply or is self-supplied and used for household purposes such as drinking, food preparation, bathing, washing dishes and clothes, flushing toilets, and watering lawns and gardens. Water withdrawn for home heating and cooling by ground-water heat pumps is also included in this category.

Evaporation.-. The process by which water is changed from a liquid to a vapor phase.

Freshwater.-- Water that contains less than 1,000 milligrams per liter (mg/L) of TDS; generally, more than $500 \mathrm{mg} / \mathrm{L}$ of TDS in water is undesirable for drinking and many industrial uses.

Ground water.-- Generally, all subsurface water, as distinct from surface water; specifically, that part of subsurface water in the saturated zone (a zone in which all interconnected openings are filled with water) where the water is under pressure equal to or greater than that of the atmosphere.

Hydroelectric water use.-- Water used in the generation of electricity at power plants where the turbine generators are driven by falling water; an instream use.

Industrial water use.-- Water used for manufacturing or processing purposes, such as fabrication; washing, cooling, and separation processes; and boiler make-up. Includes use by industries such as steel, chemical and allied products, shipbuilding, petroleum refining, truck assembly, printers and publishers, clothing manufacturers, paper and allied products plants, and food and seafood processors. 
Instream use.-- Water use that takes place within the stream channel for such purposes as hydroelectricpower generation, navigation, water-quality improvement, fish propagation, and recreation.

Irrigation water use.-- Artificial application of water on the land surface to assist in the growing of farm and nursery crops or to maintain vegetative growth in recreational lands, such as parks and golf courses.

Mining water use.-- Water used for extracting minerals such as coal. Also includes uses associated with stone, sand, and gravel quarrying, dewatering, milling (crushing, screening, washing, flotation), and other preparations usually performed at the mine site or as part of a mining activity. Dewatering in the construction of subway tunnels is also included.

Public supply water use.-- Water withdrawn by public and private water suppliers and delivered for a variety of uses, such as domestic, commercial, and industrial. Public water suppliers include municipalities, towns, or counties having incorporated governments. Private water suppliers include unincorporated communities, subdivisions with central water supplies, trailer parks, apartment buildings, and migrant labor camps with independent supply systems.

Reclaimed wastewater.- Wastewater-treatment-plant effluent that has been diverted or intercepted for use before it reaches a natural waterway or aquifer.

Saline water.-- Water that contains more than $1,000 \mathrm{mg} / \mathrm{L}$ of TDS ("slightly saline"--1,000 to 3,000 mg/L; "moderately saline"--3,000 to $10,000 \mathrm{mg} / \mathrm{L}$; "very saline"--10,000-35,000 mg/L).

Self-supplied water.-- Water withdrawn by a user of a surface-water or ground-water source and not furnished by a public supply. Homes and small communities relying on individual wells are included in this category.

Surface water... A body of water on the land surface, such as a stream or a lake.

Thermoelectric-power water use.-- Water used in the process of the generation of electricity by other than hydroelectric processes.

Withdrawal.-- Water diverted from a surface-water source or removed from an aquifer for use. 


\title{
WATER WITHDRAWAL AND USE IN MARYLAND, 1990-91
}

\author{
By Judith C. Wheeler
}

\begin{abstract}
This report summarizes the results of a study by the U.S. Geological Survey, in cooperation with the Maryland Water Resources Administration and the Maryland Geological Survey, to estimate amounts of fresh and saline water withdrawn and used in Maryland during 1990-91.
\end{abstract}

During 1990, about 1,460 Mgal/d (million gallons per day) of freshwater was withdrawn from surface-water and ground-water sources in Maryland. Of this amount, 1,210 Mgal $/ \mathrm{d}(83$ percent) was used in the State and $248 \mathrm{Mgal} / \mathrm{d}$ (17 percent) was transferred to surrounding States and the District of Columbia for water supply. About $7.5 \mathrm{Mgal} / \mathrm{d}$ of freshwater was imported from bordering States for use in Maryland.

During 1991, total freshwater withdrawals in Maryland increased to about 1,500 Mgal/d, with 1,250 Mgal/d used in the State and 249 $\mathrm{Mgal} / \mathrm{d}$ transferred to surrounding States and the District of Columbia. About $6.6 \mathrm{Mgal} / \mathrm{d}$ of freshwater was imported from bordering States for use in Maryland.

During 1990-91, most freshwater withdrawals (1,220 Mgal/d during 1990 and 1,250 Mgal/d during 1991 or about 83 percent of total for each year) were from surface-water sources. The largest surface-water withdrawals in the State, greater than $100 \mathrm{Mgal} / \mathrm{d}$, were in Montgomery and Baltimore Counties. Reservoirs and rivers in these counties were the sources for public suppliers that serve the Baltimore City and District of Columbia metropolitan areas. More than 70 percent of the fresh surface water (about 870 Mgal/d during 1990 and $875 \mathrm{Mgal} / \mathrm{d}$ during 1991) was withdrawn and used in the Potomac drainage basin whereas most ground water (about $170 \mathrm{Mgal} / \mathrm{d}$ during 1990 and $184 \mathrm{Mgal} / \mathrm{d}$ during 1991) was withdrawn and used in the Upper Chesapeake drainage basin. The Potomac Group aquifers were the largest source of ground water (26.6 percent of total ground-water withdrawals) in each year.

The population of Maryland served by public water-supply systems increased slightly from 3.94 million during 1990 to 3.97 million during 1991. In addition, during the peak tourist season (from May to September), the Ocean City watersupply system served approximately 268,000 more individuals than the base population of about 12,000 . During both years, surface water was used by about 69 percent of the State's population and ground water was used by the remaining 31 percent.

Ten water-use categories represent the major demands on the surface-water and ground-water resources of the State during 199091: Public supply, domestic, commercial, industrial, mining, thermoelectric power,

hydroelectric power, livestock, irrigation, and aquaculture.

Notable facts about these uses are:

- Public supply--798 Mgal/d of freshwater was withdrawn in 1990 (826 Mgal/d during 1991) and delivered for use to residences, commercial establishments, and industries. Public suppliers withdrew the largest quantities of water in the State. The largest user of surface water for public supply was Baltimore City with about $135 \mathrm{Mgal} / \mathrm{d}$ withdrawn for use during 1990 and $127 \mathrm{Mgal} / \mathrm{d}$ during 1991.

- Domestic--484 Mgal/d of freshwater was used during 1990 (490 Mgal/d during 1991). About 414 Mgal/d during 1990 and $420 \mathrm{Mgal} / \mathrm{d}$ during 1991 were received from public suppliers. About 69.9 Mgal/d during 1990 and $71.4 \mathrm{Mgal} / \mathrm{d}$ during 1991 were self-supplied. All self-supplied domestic 
water withdrawals were from ground-water sources.

- Industrial-123 Mgal/d of freshwater was used during 1990 (116 Mgal/d during 1991). About 70.1 $\mathrm{Mgal} / \mathrm{d}$ during 1990 and 67.2 Mgal/d during 1991 were self-supplied; the remaining water used was delivered by public suppliers. Industries also used $379 \mathrm{Mgal} / \mathrm{d}$ of saline or brackish surface water during 1990 (312 Mgal/d during 1991). About 62.5 $\mathrm{Mgal} / \mathrm{d}$ of reclaimed wastewater was used during each year.

- Mining--28.0 Mgal/d of freshwater was used during 1990 (25.3 Mgal/d during 1991). Brackish or saline surface-water withdrawals used in mining operations decreased 82 percent from $21.3 \mathrm{Mgal} / \mathrm{d}$ in 1990 to $3.77 \mathrm{Mgal} / \mathrm{d}$ in 1991 due mainly to reduced dredging operations.

- Thermoelectric power-421 Mgal/d of freshwater was used during 1990 (416 Mgal/d during 1991). In addition, about $4,550 \mathrm{Mgal} / \mathrm{d}$ of saline surface water was withdrawn for cooling condensers during 1990. During 1991, saline surface-water withdrawals increased to $5,760 \mathrm{Mgal} / \mathrm{d}$.

- Hydroelectric power (instream water use)--25,900 $\mathrm{Mgal} / \mathrm{d}$ of freshwater was used for the production of electricity during 1990 (21,900 Mgal/d during 1991). Although the amount of water diverted through some plants was considerable, the amount of consumptive use was negligible.

- Livestock-About 10.4 Mgal/d of freshwater was used during each year of the 2-year period. About $2.44 \mathrm{Mgal} / \mathrm{d}$ was from surface-water sources and $7.95 \mathrm{Mgal} / \mathrm{d}$ was from ground-water sources.

- Irrigation-29.1 Mgal/d of freshwater was used during 1990 (50.4 Mgal/d during 1991). Most of the water (22.8 Mgal/d during 1990 and $41.1 \mathrm{Mgal} / \mathrm{d}$ during 1991) was used for irrigating farm crops.

- Aquaculture--9.37 Mgal/d of freshwater was used during 1990 (11.6 Mgal/d during 1991). Saline surface-water withdrawals increased from 9.58 $\mathrm{Mgal} / \mathrm{d}$ during 1990 to $12.5 \mathrm{Mgal} / \mathrm{d}$ during 1991 .

\section{INTRODUCTION}

Maryland has a total land and water area of $12,303 \mathrm{mi}^{2}$ and is subdivided into 23 counties and Baltimore City (fig. 1). The State has abundant surface-water ${ }^{1}$ and ground-water resources. As the demand for water increases, however, additional stress is placed on these resources. Effective water-resource management depends, in part, on current and accurate water-withdrawal and use data. Such data are valuable for evaluating effects of withdrawals on the State's water resources, identifying current water-use patterns, and estimating future water demands. The study on which this report is

1. Words that are bold are found in the "Glossary" section of the report. based was conducted by the U.S. Geological Survey, as part of the National Water-Use Information Program of collecting and compiling reliable site-specific and aggregate water-use information at State and national levels. The study was conducted in cooperation with the Maryland Water Resources Administration (WRA) and the Maryland Geological Survey. The results of similar studies in 1986, 1987, and 1988-89 are summarized by Wheeler (1990, 1991, and 1992).

\section{Purpose and Scope}

This report summarizes the amounts of fresh and saline water withdrawn and used in Maryland during 1990 and 1991. The water-use data are discussed briefly and presented in graphs, tables, and maps organized by counties, type of use, drainage basins, and aquifers.

In this report, the amount of water withdrawn from sources in each county is distinguished from the amount of water used in each county. Withdrawals in each county include all water withdrawn whether or not it is transferred to another county or State. Water use is the amount of water actually used in a particular county or drainage basin, including (1) water withdrawn for use in the county or basin and (2) water imported from another county, basin, or State. Amounts of self-supplied water and water delivered from public-supply systems are presented for each category of use.

The water-use categories discussed in this report are public supply, domestic, commercial, industrial, mining, thermoelectric power, hydroelectric power, livestock, irrigation, and aquaculture. Water withdrawn by a public or private water utility and delivered to a variety of users is designated as a "public supply." If a public supply is not available or is not used, the water is classified as "self-supplied." Homes and small communities relying on individual wells are classified as domestic self-supplied water users. Commercial use not only includes typical businesses such as restaurants, motels, car washes, and office buildings, but also institutions such as schools, churches, and military installations. Thermoelectric power includes electrical energy generated in steam-electric plants and those using nuclear fuel. Water used for the generation of electricity by hydroelectric 


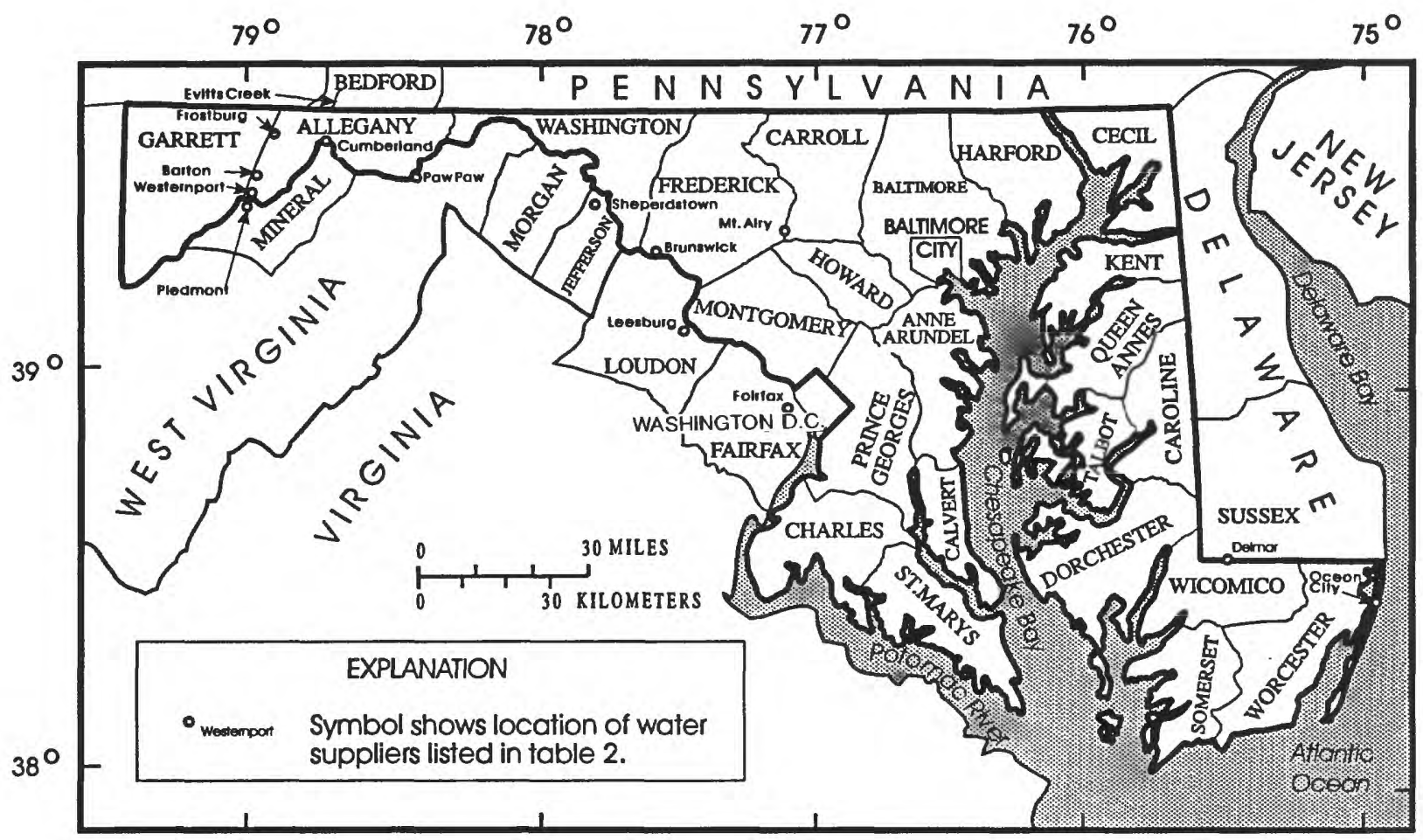

Figure 1. The counties of Maryland and selected adjacent counties of Virginia, West Virginia, and Pennsylvania.

power plants is also discussed in this report but the quantities of water used are not included in the freshwater totals because this is considered an "instream" water use and not a withdrawal-that is, water use takes place within the stream channel at the dam, where turbine generators are driven by falling water.

\section{Methods of Data Collection and Estimation}

Most of the water-use data on public suppliers, commercial and industrial facilities, mines, and thermoelectric power plants were obtained from pumpage reports submitted to WRA by users withdrawing $0.01 \mathrm{Mgal} / \mathrm{d}$ or more.

Monthly and annual withdrawal data are stored in a computerized data base by WRA. The U.S. Geological Survey, in cooperation with WRA and the Maryland Department of the Environment (MDE), maintains the Maryland SiteSpecific Water-Use Data System (SSWUDS), that is designed to store monthly water-withdrawal data from the WRA and return-flow data from the MDE for users that withdraw or return 0.01 $\mathrm{Mgal} / \mathrm{d}$ or more. The WRA's data base and
SSWUDS were used in the preparation of this report. Water-use data for users of less than 0.01 $\mathrm{Mgal} / \mathrm{d}$ were estimated from the average daily allocations established in water-appropriation and use permits which are required by WRA for all water users except self-supplied domestic users and agricultural irrigators using less than $0.01 \mathrm{Mgal} / \mathrm{d}$.

Data on domestic, hydroelectric power, livestock, and irrigation water use were estimated using the following methods:

Self-supplied domestic withdrawals were estimated by determining the percentage of yearround housing units not served by public suppliers (U.S. Department of Commerce, 1990b, p. 92) and multiplying that percentage by the total population for each county (1990 county population data from U.S. Department of Commerce, 1990a, table 1, p. 1-12 and 1991 county population data compiled from Maryland Department of State Planning, 1990). The total 
unserved population number was then multiplied by $80 \mathrm{gal} / \mathrm{d}$, the estimated per capita water use in Maryland (J.R. Herring, Maryland Water Resources Administration, oral commun., 1992).

\section{Hydroelectric-power water use was estimated}

based on annual electric power generation data obtained from the Department of Energy, Energy Information Administration and a coefficient for water used per KWh (S.B. Weisberg, Martin Marietta Environmental Systems, written commun., 1986). Reported water-use data were used for some of the facilities.

Livestock water use was estimated based on the number of farm animals in each county (U.S. Department of Commerce, 1988) and the average amount of water used for drinking and maintenance per animal (U.S. Environmental Protection Agency, 1973, p. 15). Because the most recent agricultural census was conducted during 1987, the same number of animals and the same water use were assumed for 1990-91. The estimates also are based on the assumption that grazing animals such as cattle and sheep consumed surface water, and poultry, hogs, and dairy cows consumed ground water.

Irrigation water use for crops was estimated from the number of acres irrigated and amount of rainfall during the growing season (based on Carr, 1991). For 1990, a water-application rate of 0.5 (acre-ft) $/ \mathrm{yr}$ per acre or about $446 \mathrm{gal} / \mathrm{d}$ per acre was used for counties on the lower Eastern Shore of Maryland (Dorchester, Somerset, Wicomico, and Worcester), and 0.3 (acre$\mathrm{ft}$ )/yr per acre or about $295 \mathrm{gal} / \mathrm{d}$ per acre was used for counties on the upper Eastern Shore (Caroline, Kent, Queen Annes, and Talbot) and the rest of the State. Irrigation water use for 1991 was estimated using 0.75 (acre-ft)/yr per acre or about $670 \mathrm{gal} / \mathrm{d}$ per acre during 1991 (L.E. Carr, Maryland Cooperative Extension Service, oral commun., 1991 and 1992).

\section{WATER USE}

During 1990, approximately 1,460 Mgal/d of freshwater was withdrawn from surfacewater and ground-water sources in Maryland. Of this amount, $1,210 \mathrm{Mgal} / \mathrm{d}$ (83 percent) was used in the State and $248 \mathrm{Mgal} / \mathrm{d}$ (17 percent) was transferred to surrounding States and the District of Columbia for water supply. About 7.5 $\mathrm{Mgal} / \mathrm{d}$ of freshwater was imported from bordering States for use in Maryland. During 1991, about 1,500 Mgal /d of freshwater was withdrawn. Of this amount, $1,250 \mathrm{Mgal} / \mathrm{d}(84$ percent) was used in the State and $249 \mathrm{Mgal} / \mathrm{d}$ (16 percent) was transferred to surrounding areas. About $6.6 \mathrm{Mgal} / \mathrm{d}$ of freshwater was imported from bordering States for use in Maryland. In addition, some public suppliers in Maryland withdraw or deliver water across county and State boundaries. Suppliers that withdraw or deliver water across county and State boundaries and the quantities delivered are shown in table 1.

Withdrawals of freshwater by county are shown in figure 2. The largest surface-water withdrawals (more than $100 \mathrm{Mgal} / \mathrm{d}$ ) were in Baltimore and Montgomery Counties. The reservoirs and rivers in these counties provide water sources for public suppliers that serve the Baltimore City and District of Columbia metropolitan areas. The smallest withdrawals (less than 4.5 $\mathrm{Mgal} / \mathrm{d}$ ) were in Howard County. The county is served primarily by the Baltimore City publicsupply system and the Washington Suburban Sanitary Commission (WSSC) system with water sources in Montgomery and Prince Georges Counties.

Freshwater withdrawals by category of use are summarized in figure 3 . Withdrawal and use data by county in 1990 and 1991 are presented in tables 3-13 in the appendix. Table 3 a summarizes total withdrawals by county in 1990; table $3 \mathrm{~b}$ summarizes total withdrawals by county in 1991 .

A comparison of total fresh surface-water and ground-water withdrawals by county during 1990 and 1991 is shown in figure 4. During each year, approximately 83 percent $(1,220$ $\mathrm{Mgal} / \mathrm{d}$ during 1990 and 1,250 Mgal/d during 1991) of the freshwater withdrawn was from surface-water sources, compared to 17 percent $(240$ $\mathrm{Mgal} / \mathrm{d}$ during 1990 and $255 \mathrm{Mgal} / \mathrm{d}$ during 1991) withdrawn from ground-water sources. Most fresh surface water (more than 100 $\mathrm{Mgal} / \mathrm{d}$ ) was withdrawn in Montgomery and Baltimore Counties (tables $3 a$ and $3 b$ ), whereas most ground water (more than $25 \mathrm{Mgal} / \mathrm{d}$ ) was withdrawn in Anne Arundel County. 
Table 1.--Maryland water suppliers cross-boundary withdrawals and deliveries, 1990-91 [See fig. 1 for locations]

\begin{tabular}{|c|c|c|c|c|}
\hline \multirow[b]{2}{*}{ Water supplier } & \multirow[b]{2}{*}{ County and State of withdrawal } & \multirow[b]{2}{*}{ County and State of use } & \multicolumn{2}{|c|}{ Amount delivered, in million gallons per day } \\
\hline & & & 1990 & 1991 \\
\hline \multirow[t]{4}{*}{ Baltimore City } & Baltimore, Md. & Anne Arundel, Md. & 9.12 & 10.00 \\
\hline & & Baltimore City & 135.22 & 127.19 \\
\hline & & Carroll, Md. & 1.18 & 1.27 \\
\hline & & Howard, Md. & 13.92 & 16.43 \\
\hline Barton & Garrett, Md. & Allegany, Md. & .09 & .09 \\
\hline \multirow[t]{2}{*}{ Brunswick } & Washington, Md. & Frederick, Md. & .16 & .22 \\
\hline & Loudoun, Va. & Frederick, Md. & .08 & .08 \\
\hline Cumberland & Bedford, Pa. & Allegany, Md. & 7.08 & 6.20 \\
\hline Delmar & Sussex, Del. & Wicomico, Md. & .35 & .35 \\
\hline Frostburg & Garrett, Md. & Allegany, Md. & .84 & .84 \\
\hline Mt. Airy & Frederick, Md. & Carroll, Md. & .23 & .23 \\
\hline \multicolumn{5}{|c|}{ Washington Suburban } \\
\hline \multirow{2}{*}{ Sanitary Commision } & Montgomery, Md. & Prince Georges, Md. & 42.06 & 42.05 \\
\hline & Prince Georges, Md. & Howard, Md. & 3.00 & 3.00 \\
\hline \multirow{2}{*}{\multicolumn{5}{|c|}{$\begin{array}{l}\text { Westernport } \\
\text { Fairfax County }\end{array}$}} \\
\hline & & & & \\
\hline Water Authority & Montgomery, Md. & Fairfax, Va. & 49.30 & 52.88 \\
\hline Leesburg & Montgomery, Md. & Loudoun, Va. & 1.40 & 1.68 \\
\hline Paw Paw & Allegany, Md. & Morgan, W. Va. & .04 & .04 \\
\hline Piedmont & Garrett, Md. & Mineral, W. Va. & .09 & .09 \\
\hline Shepherdstown & Washington, Md. & Jefferson, W. Va. & .36 & .35 \\
\hline Washington Aqueduct & Montgomery, Md. & District of Columbia & 196.39 & 194.24 \\
\hline
\end{tabular}

The largest drainage basins in Maryland are the Potomac and the Upper Chesapeake (fig. 5). During 1990 and 1991, over 70 percent of total fresh surface-water withdrawals were from streams in the Potomac Basin. During 1990, about $870 \mathrm{Mgal} / \mathrm{d}$ of fresh surface water was withdrawn and used in this basin compared to $300 \mathrm{Mgal} / \mathrm{d}$ withdrawn and used in the Upper Chesapeake Basin. In addition, about $17 \mathrm{Mgal} / \mathrm{d}$ of fresh surface water was withdrawn in the Potomac Basin and transferred to the Chesapeake Basin. About $27 \mathrm{Mgal} / \mathrm{d}$ of fresh surface water was withdrawn in the Upper Chesapeake Basin and transferred to the Potomac Basin for use.

During 1991, about $875 \mathrm{Mgal} / \mathrm{d}$ of fresh surface water was withdrawn and used in the Potomac Basin compared to $318 \mathrm{Mgal} / \mathrm{d}$ withdrawn and used in the Upper Chesapeake Basin. In addition, about $17 \mathrm{Mgal} / \mathrm{d}$ of fresh surface water was withdrawn in the Potomac Basin and transferred to the Upper Chesapeake Basin for use. About $31 \mathrm{Mgal} / \mathrm{d}$ of fresh surface water was withdrawn in the Upper Chesapeake Basin, and transferred to the Potomac Basin for use. Each year, less than 1 percent of all fresh surface water withdrawn was from the parts of the Monongahela, Susquehanna, and Delaware River (amount too small to show on graph) drainage basins in Maryland.

During 1990, about 71 percent (170 Mgal/d) of fresh ground-water was withdrawn and used in the Upper Chesapeake Basin, compared to about 27 percent $(65 \mathrm{Mgal} / \mathrm{d})$ in the Potomac Basin. During 1991, total ground-water withdrawals increased to $184 \mathrm{Mgal} / \mathrm{d}$ (72 percent) in the Upper Chesapeake Basin and remained the same at $65 \mathrm{Mgal} / \mathrm{d}$ ( 25 percent) in the Potomac Basin. Only about 2 percent of total groundwater withdrawals were from sites in the Monongahela, Susquehanna, and Delaware River (amount too small to show on graph) drainage basins. 

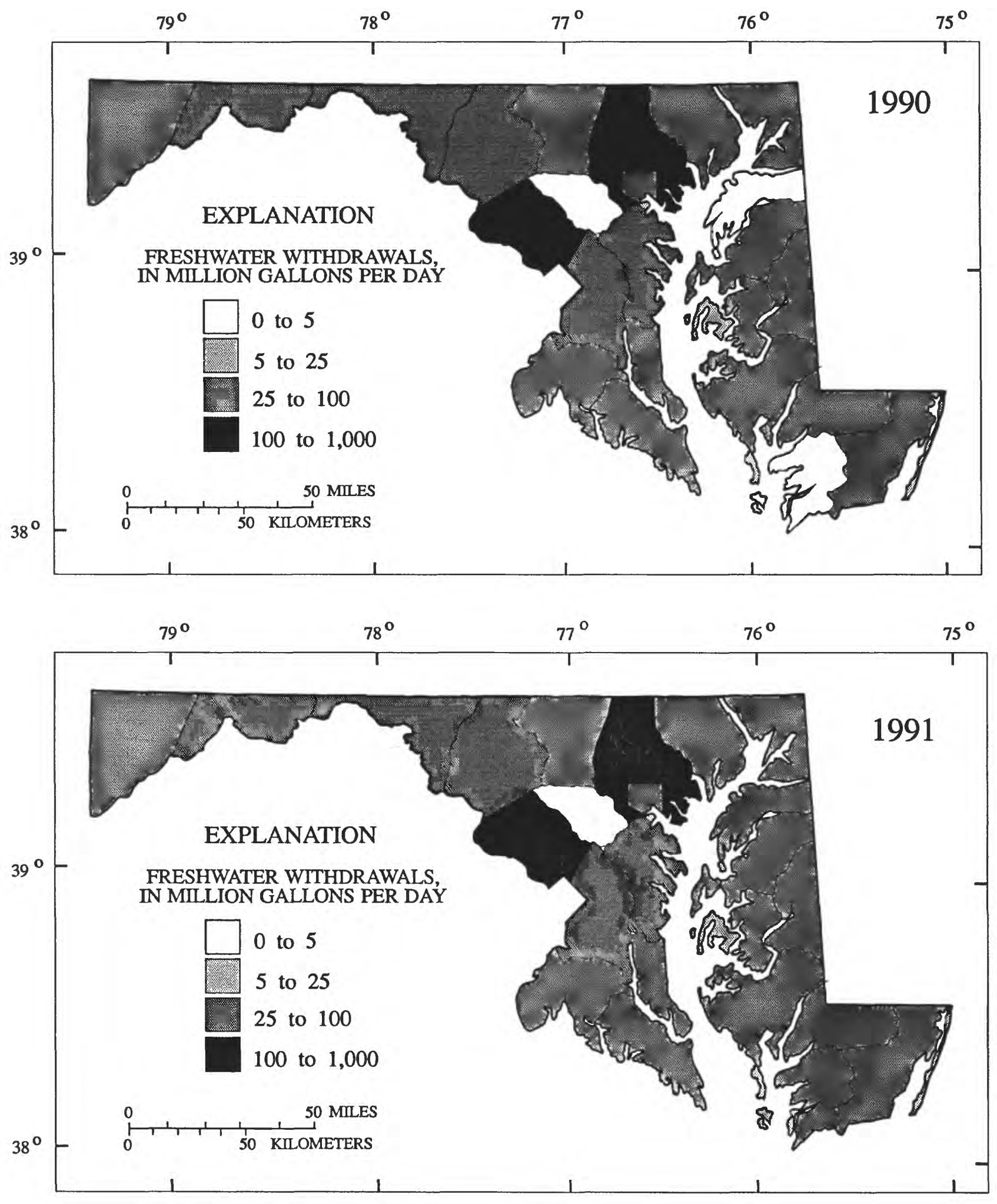

Figure 2. Freshwater withdrawals in Maryland, by county, 1990-91. 

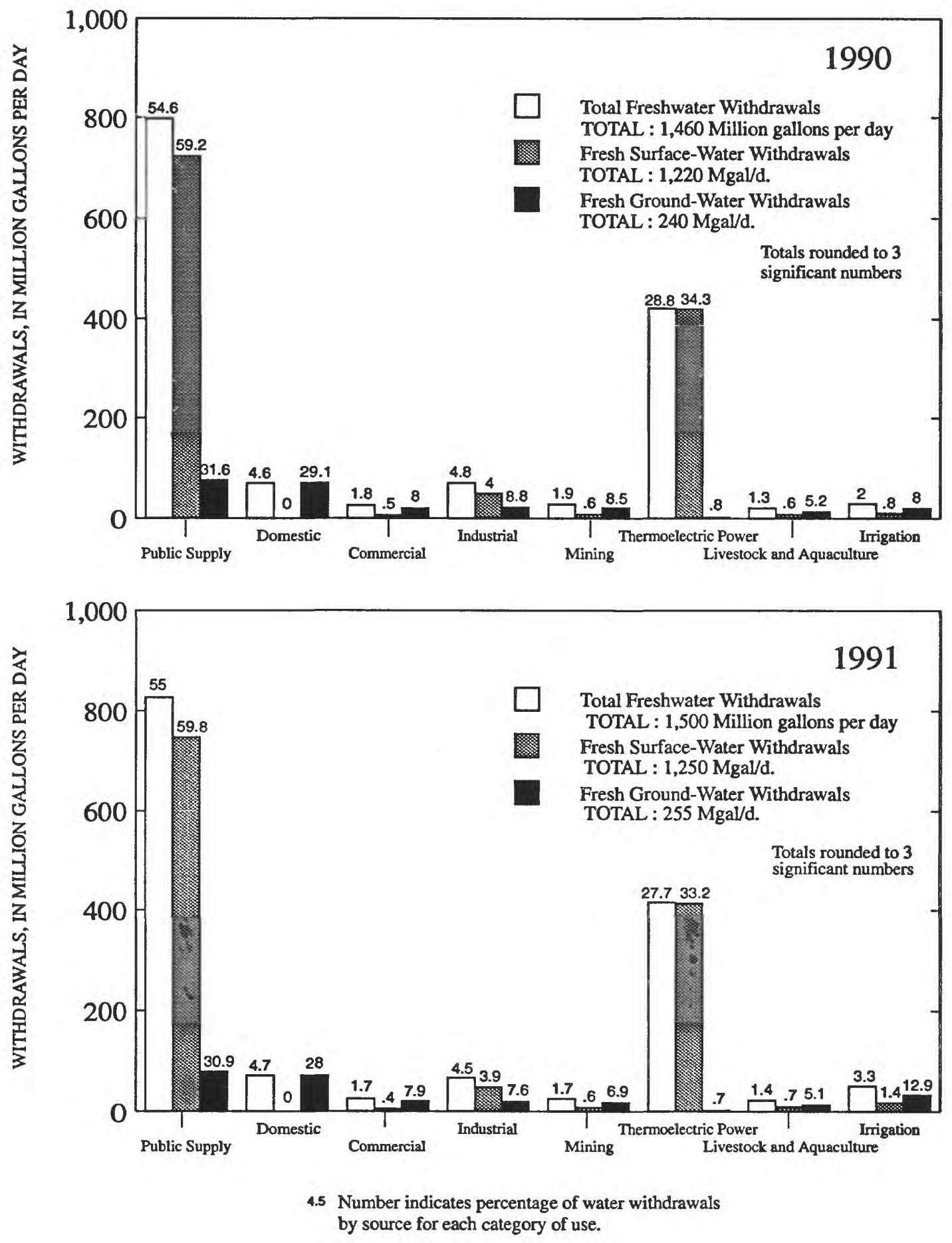

Figure 3. Freshwater withdrawals and source of water in Maryland, by category of use, 1990-91. 

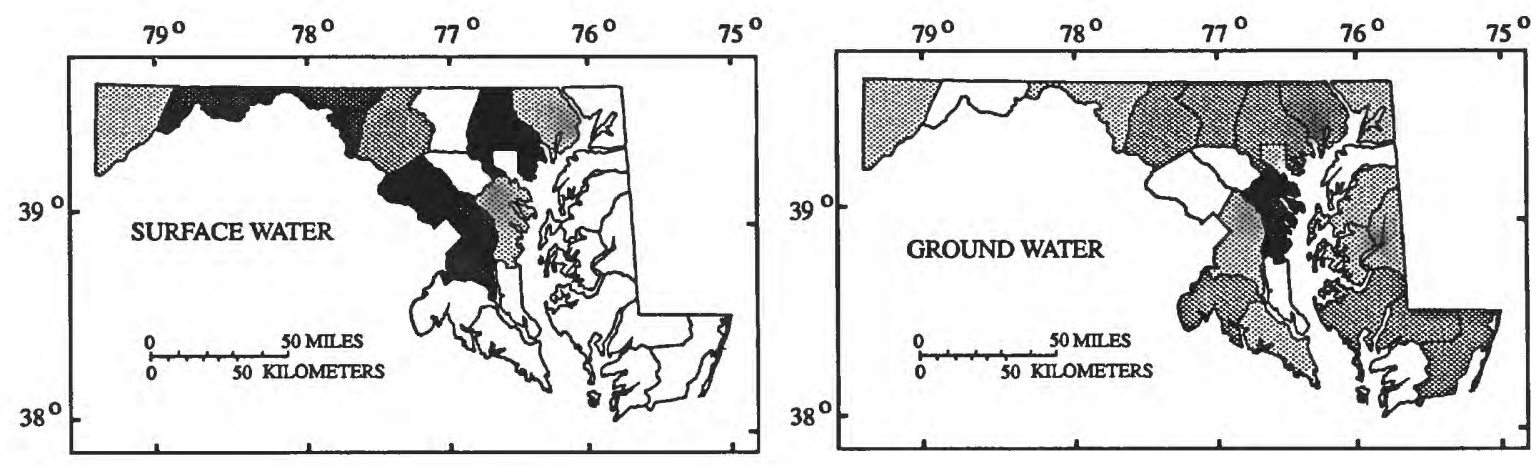

1990
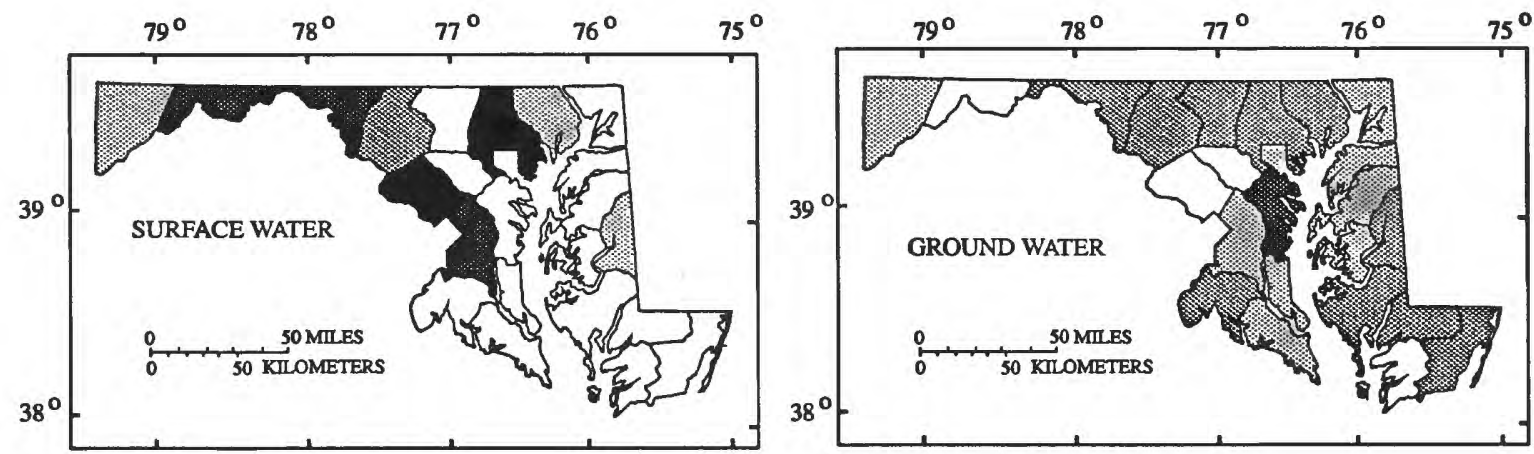

1991

EXPLANATION

FRESHWATER WITHDRAWALS, IN MILLION GALLONS PER DAY

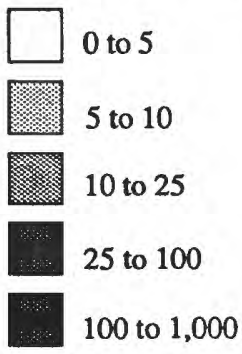

PERCENT OF TOTAL FRESHWATER WITHDRAWALS

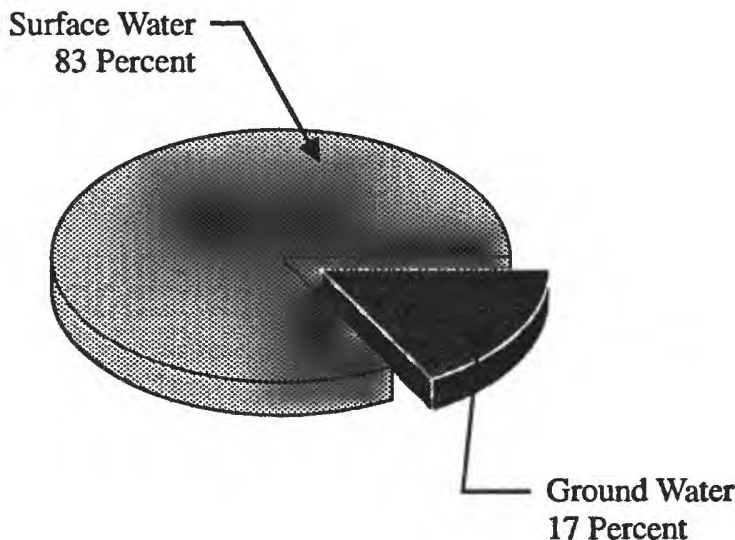

Figure 4. Fresh surface-water and ground-water withdrawals in Maryland, by county, 1990-91. 


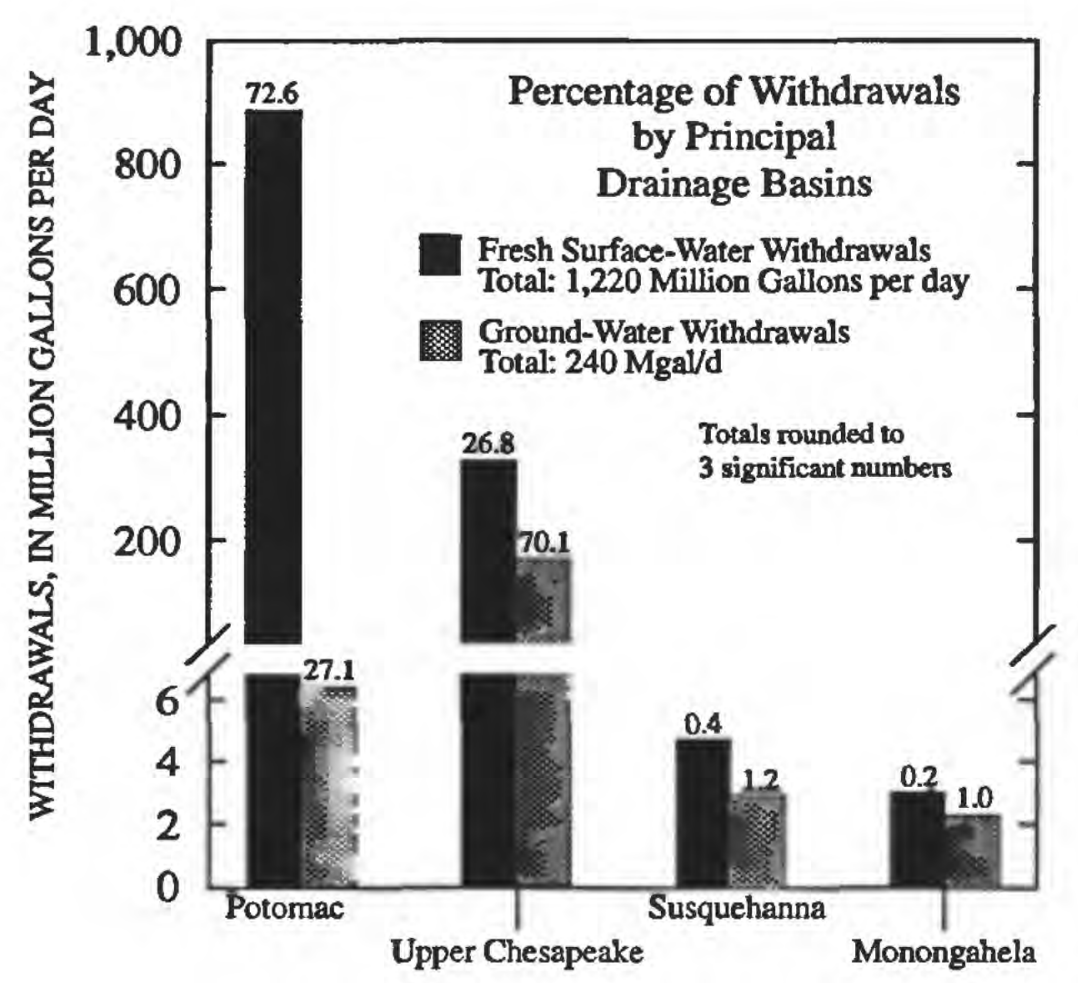

1990

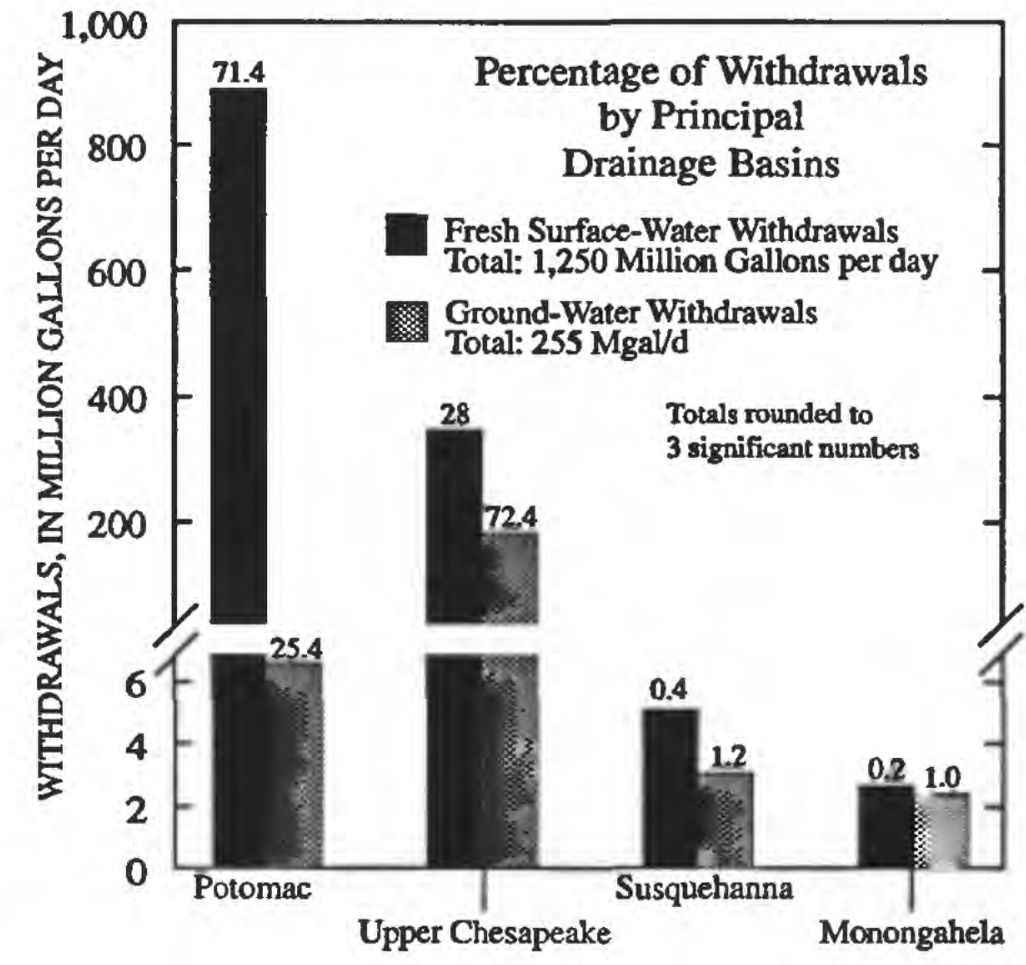

1991

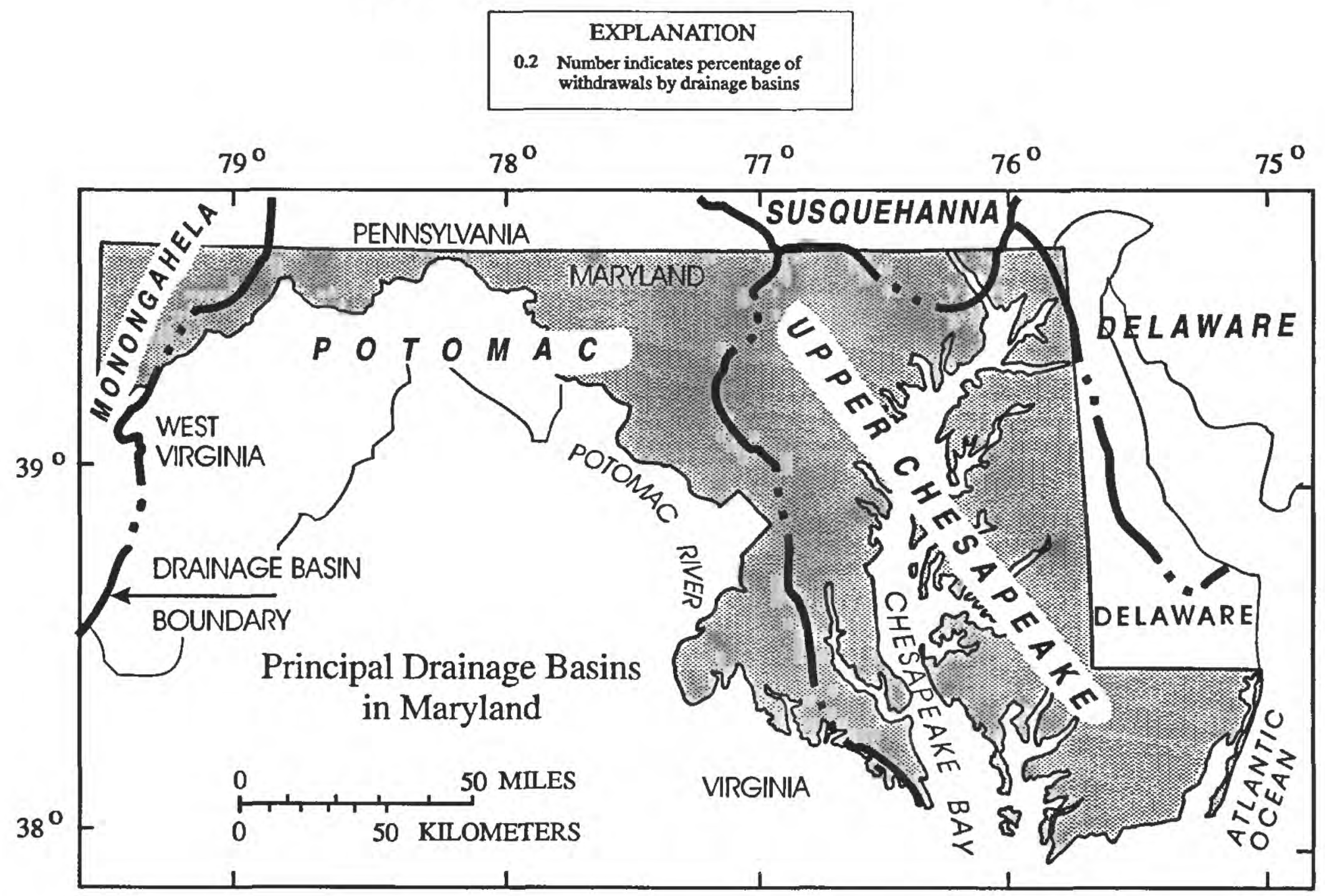

Figure 5. Fresh surface-water and ground-water withdrawals in Maryland, by principal drainage basin, 1990-91. 
Estimated percentages of ground-water withdrawals by principal aquifers during 1990 and 1991 are shown in figure 6. The map and hydrogeologic section show the geographic distribution of the principal aquifers in Maryland (U.S. Geological Survey, 1990, p. 294). The Potomac Group aquifers were the largest source of ground water with $64 \mathrm{Mgal} / \mathrm{d}$ withdrawn during 1990 and $68 \mathrm{Mgal} / \mathrm{d}$ during 1991 (26.6 percent of total ground-water withdrawals), followed by the Columbia and Piedmont aquifers with about $36 \mathrm{Mgal} / \mathrm{d}$ during 1990 and 38 Mgal/d during 1991 (about 15 percent). The smallest amount of water was withdrawn from the Newark Group aquifers with about 2 $\mathrm{Mgal} / \mathrm{d}$ withdrawn each year (0.9 percent).

\section{Population and Water-Use Trends}

The population of Maryland increased from 4,780,000 during 1990 (U.S Department of Commerce, 1990a) to 4,830,000 in 1991 (estimates based on projections from Maryland Department of State Planning, 1990). Population and wateruse data for 1990 and 1991 are presented in table 2. The population served by public water-supply systems increased from 3.94 million during 1990 to 3.97 million during 1991. During each year, surface water was used by about 69 percent of the population and ground water was used by 31 percent of the population.

Population and water-use trends in Maryland from 1950 to 1991 are shown in figure 7. During 1950, about 2.34 million people used approximately $400 \mathrm{Mgal} / \mathrm{d}$ of freshwater. Population and water use increased steadily through the 1950's and 1960's. Subsequently, however, population growth slowed, increasing from 3.92 million people in 1970 to 4.83 million in 1991 . Water use during the same period leveled off in the early 1970 's at about $1,500 \mathrm{Mgal} / \mathrm{d}$, then decreased over the rest of the decade. During 1980 , water use was about 1,400 Mgal/d. Possible explanations for the decrease in water use include changing economic conditions, declining water use among certain industries, and increasing use of conservation techniques and fixtures. However, freshwater use increased overall from 1985 to 1991 , from about $1,400 \mathrm{Mgal} / \mathrm{d}$ to about $1,500 \mathrm{Mgal} / \mathrm{d}$, primarily because of increased withdrawals for cooling purposes by power plants, and for irrigation and public-supply distribution.

\section{Public Supply}

The largest amount of water withdrawn in the State, $798 \mathrm{Mgal} / \mathrm{d}$ during 1990 and 826 Mgal/d during 1991 (55 percent of total freshwater withdrawals; fig. 3), was by public-supply systems operated by municipalities, counties and towns, and private utilities. Public suppliers delivered water to 82 percent of the total population during both 1990 and 1991 (table 2). Water was delivered for a variety of uses including domestic, commercial, and industrial uses (tables $4 \mathrm{a}$ and $4 \mathrm{~b}$ ). In addition, each year during the peak tourist season (May through September), the Ocean City water-supply system in Worcester County served about 268,000 more people than the base population of about 12,000 (Andrews, Miller \& Assoc., Inc., 1990, p. 2-9).

Most public suppliers in central and western Maryland rely on surface-water sources. Some of these suppliers withdraw and deliver water across county and State boundaries as shown in table 1. The largest user of surface water for public supply is Baltimore City. During 1990, about $135 \mathrm{Mgal} / \mathrm{d}$ was withdrawn for use by the city compared to about $127 \mathrm{Mgal} / \mathrm{d}$ during 1991. In addition, Baltimore City supplied about 127 $\mathrm{Mgal} / \mathrm{d}$ during 1990 and $121 \mathrm{Mgal} / \mathrm{d}$ during 1991 to parts of Baltimore, Howard, Anne Arundel, and Carroll Counties. Another large user of surface water for public supply in Maryland is the WSSC, which withdrew $174 \mathrm{Mgal} / \mathrm{d}$ during 1990 and $180 \mathrm{Mgal} / \mathrm{d}$ during 1991 and delivered water to most of Montgomery and Prince Georges Counties and part of Howard County.

The Potomac River in Maryland is a water source for several public suppliers in Virginia and West Virginia and for the U.S. Army Corps of Engineers, who delivers water to the District of Columbia through the Washington Aqueduct. During 1990, about $50.7 \mathrm{Mgal} / \mathrm{d}$ of fresh surface water was withdrawn from the river and transferred to Virginia and West Virginia for use, compared to $54.6 \mathrm{Mgal} / \mathrm{d}$ withdrawn and transferred during 1991. During 1990, the Washington Aqueduct conveyed about $196 \mathrm{Mgal} / \mathrm{d}$ from the Potomac River for public-supply deliveries to the District, compared to $194 \mathrm{Mgal} / \mathrm{d}$ conveyed during 1991. 
Several municipalities in Maryland obtained all or part of their water supply from bordering States during 1990 and 1991, including Cumberland in Allegany County, which received $7.08 \mathrm{Mgal} / \mathrm{d}$ of surface-water during 1990 (6.20 Mgal/d during 1991) from two impoundments on Evitts Creek in Bedford County, Pennsylvania; Brunswick in Frederick County, which received about $0.08 \mathrm{Mgal} / \mathrm{d}$ each year from springs in Loudoun County, Virginia; and Delmar in Wicomico County, which received $0.35 \mathrm{Mgal} / \mathrm{d}$ each year from wells in Sussex County, Delaware.

Most public suppliers that rely on groundwater sources are in the eastern and southern parts of Maryland. In counties east of Chesapeake Bay, all public suppliers rely on ground water. The largest ground-water withdrawals for public supply, however, are in Anne Arundel County. During 1990, about $26 \mathrm{Mgal} / \mathrm{d}$ was withdrawn by public suppliers in the county compared to $27.8 \mathrm{Mgal} / \mathrm{d}$ during 1991.

\section{Domestic}

Domestic users in Maryland receive water from public-supply systems and from self-supplied sources (tables 5a and 5b). During 1990, total use (withdrawals plus deliveries) was 484 $\mathrm{Mgal} / \mathrm{d}$, of which $414 \mathrm{Mgal} / \mathrm{d}$ was delivered by public suppliers. Eighteen percent of the total population $(843,000$ people) withdrew about 69.9 $\mathrm{Mgal} / \mathrm{d}$ from privately owned wells (self-supplied). Domestic water use increased during 1991 to $490 \mathrm{Mgal} / \mathrm{d}$, of which $420 \mathrm{Mgal} / \mathrm{d}$ was delivered by public suppliers. As in 1990, 18 percent of the total population $(860,000$ people) withdrew about $71.4 \mathrm{Mgal} / \mathrm{d}$ from self-supplied sources. All self-supplied water withdrawn for domestic use was assumed to be from ground water.

\section{Commercial}

Commercial users, including educational institutions and military installations, receive water from public-supply systems and from privately owned wells. Total commercial use during 1990 was $113 \mathrm{Mgal} / \mathrm{d}$ (table 6a), of which about $87.1 \mathrm{Mgal} / \mathrm{d}$ (77 percent) was provided by public suppliers and about $25.8 \mathrm{Mgal} / \mathrm{d}$ (23 percent) was self-supplied. During 1991, total commercial use was $112 \mathrm{Mgal} / \mathrm{d}$ (table $6 \mathrm{~b}$ ), of which about $86.8 \mathrm{Mgal} / \mathrm{d}$ (78 percent) was provided by public suppliers and about 25.1 $\mathrm{Mgal} / \mathrm{d}$ (22 percent) was self-supplied.

\section{Industrial}

Maryland is located within a regional manufacturing belt that extends along the eastern seaboard of the United States. Heavy and light industries are important to the State's economy. Heavy industries include steel, chemical and allied products, shipbuilding, petroleum refining, and truck-assembly. Prominent light industries include food processing, printing, publishing, and clothing manufacturing. Water used by industries is from self-supplied and public-supply systems. Major water uses include washing and separation, cooling of industrial machinery, refrigeration, boiler make-up, product manufacturing, and dust control.

During 1990, about $123 \mathrm{Mgal} / \mathrm{d}$ of freshwater was used by industries in Maryland (table 7a). Of that amount, $70.1 \mathrm{Mgal} / \mathrm{d}$ or 57 percent was self-supplied and $52.4 \mathrm{Mgal} / \mathrm{d}$ (43 percent) was provided by public suppliers. Industries used less water during 1991, about $116 \mathrm{Mgal} / \mathrm{d}$ (table 7b), of which $67.2 \mathrm{Mgal} / \mathrm{d}$ (58 percent) was self-supplied and $49.2 \mathrm{Mgal} / \mathrm{d}$ (42 percent) was provided by public suppliers. Industries also used $379 \mathrm{Mgal} / \mathrm{d}$ during 1990 and $312 \mathrm{Mgal} / \mathrm{d}$ during 1991 of brackish or saline surface water. About $62.5 \mathrm{Mgal} / \mathrm{d}$ of reclaimed wastewater was used each year in steel production primarily for two types of purposes. The first is noncontact cooling--that is, the water is used for heat exchange such as in the cooling of machinery or furnace structures. The second is contact cooling and cleaning of steel in the production process. Some reclaimed wastewater is also treated then recycled.

Industries in Allegany County had the largest fresh surface-water withdrawals during both years $(45.06 \mathrm{Mgal} / \mathrm{d}$ in 1990 and $44.99 \mathrm{Mgal} / \mathrm{d}$ in 1991). Baltimore County had the largest salinesurface water withdrawals--372.6 Mgal/d (1990) and $304.8 \mathrm{Mgal} / \mathrm{d}$ (1991), as well as the largest reclaimed wastewater use $(62.5 \mathrm{Mgal} / \mathrm{d})$ for the period. The largest ground-water withdrawals for industrial use for both years were in Baltimore City with $4.52 \mathrm{Mgal} / \mathrm{d}$ in 1990 and 4.68 $\mathrm{Mgal} / \mathrm{d}$ in 1991. 


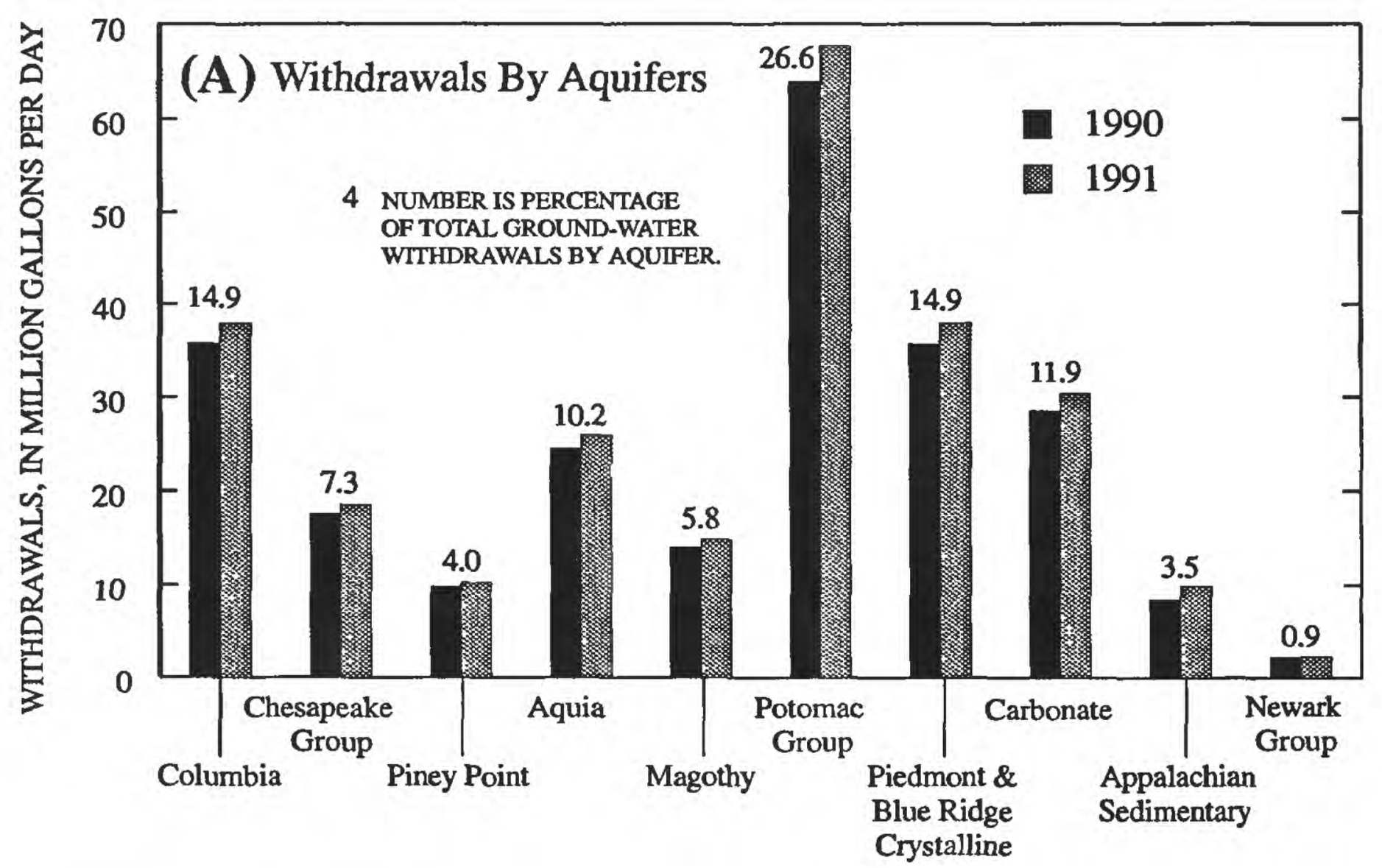

(B) Hydrogeologic Section

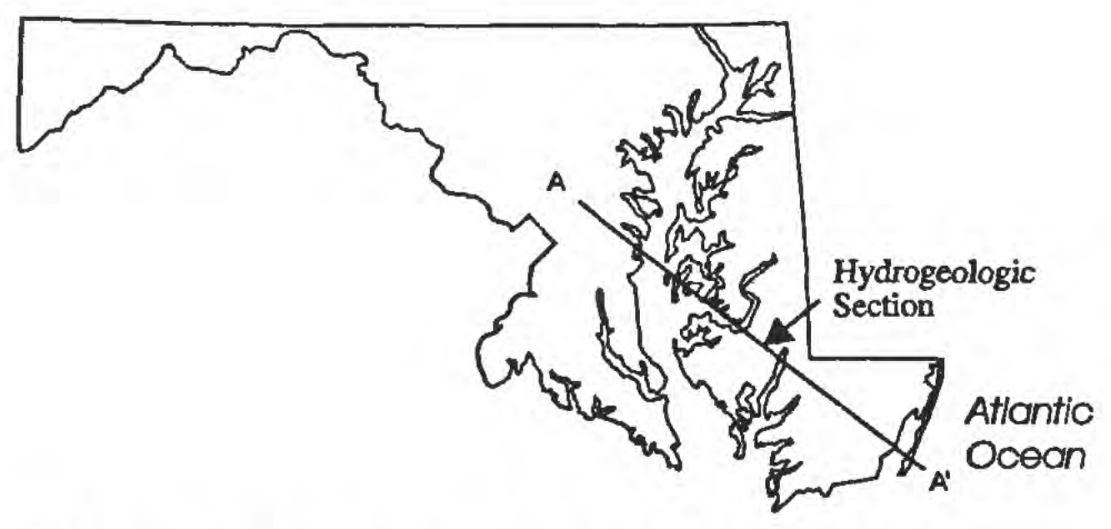

Principal aquifers shown in hydrogeologic section

Piedmont and Blue Ridge crystalline (1)

Potomac Group (2)

Magothy (3)

Not a princlpal aquifer (4)

Aquio (5)

Piney Point (6)

Cheasapeake Group (7)

Columbia (8)

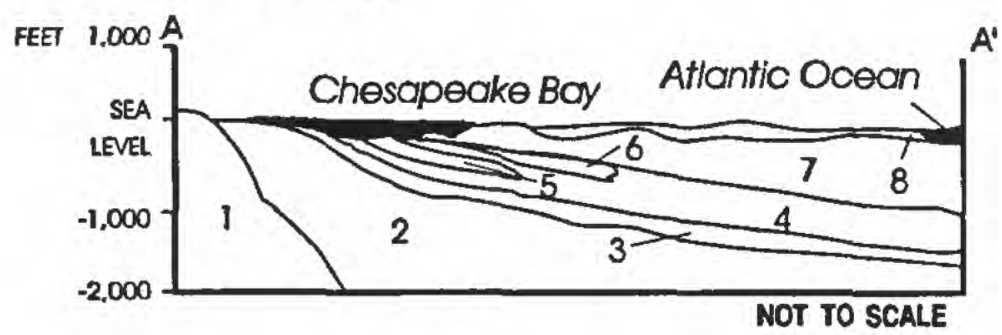

(C) Aquifers

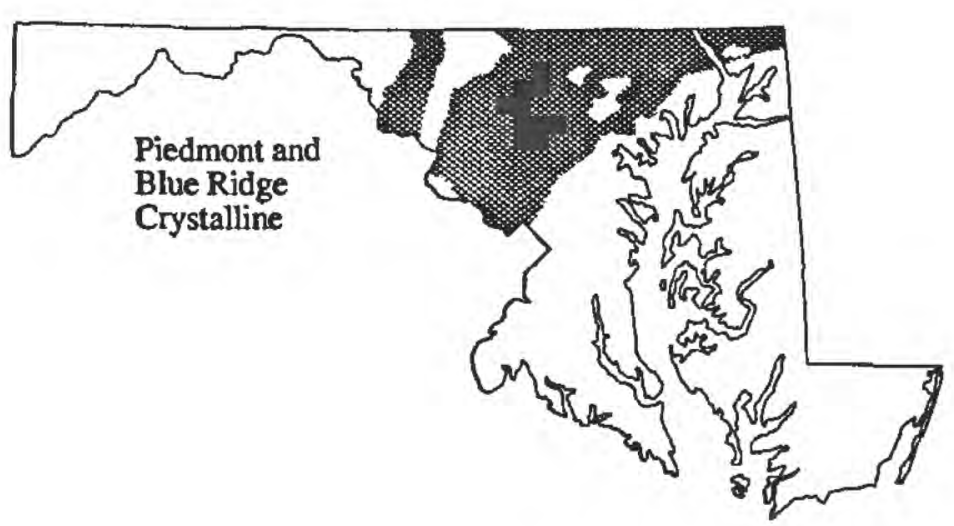

Figure 6. Ground-water withdrawals in Maryland, by principal aquifers, 1990-91. (A) Withdrawals by aquifer. (B) Trace of generalized hydrologic section (A-A'). (C) Geographic distribution of use for principal aquifers. 


\section{AQUIFERS}
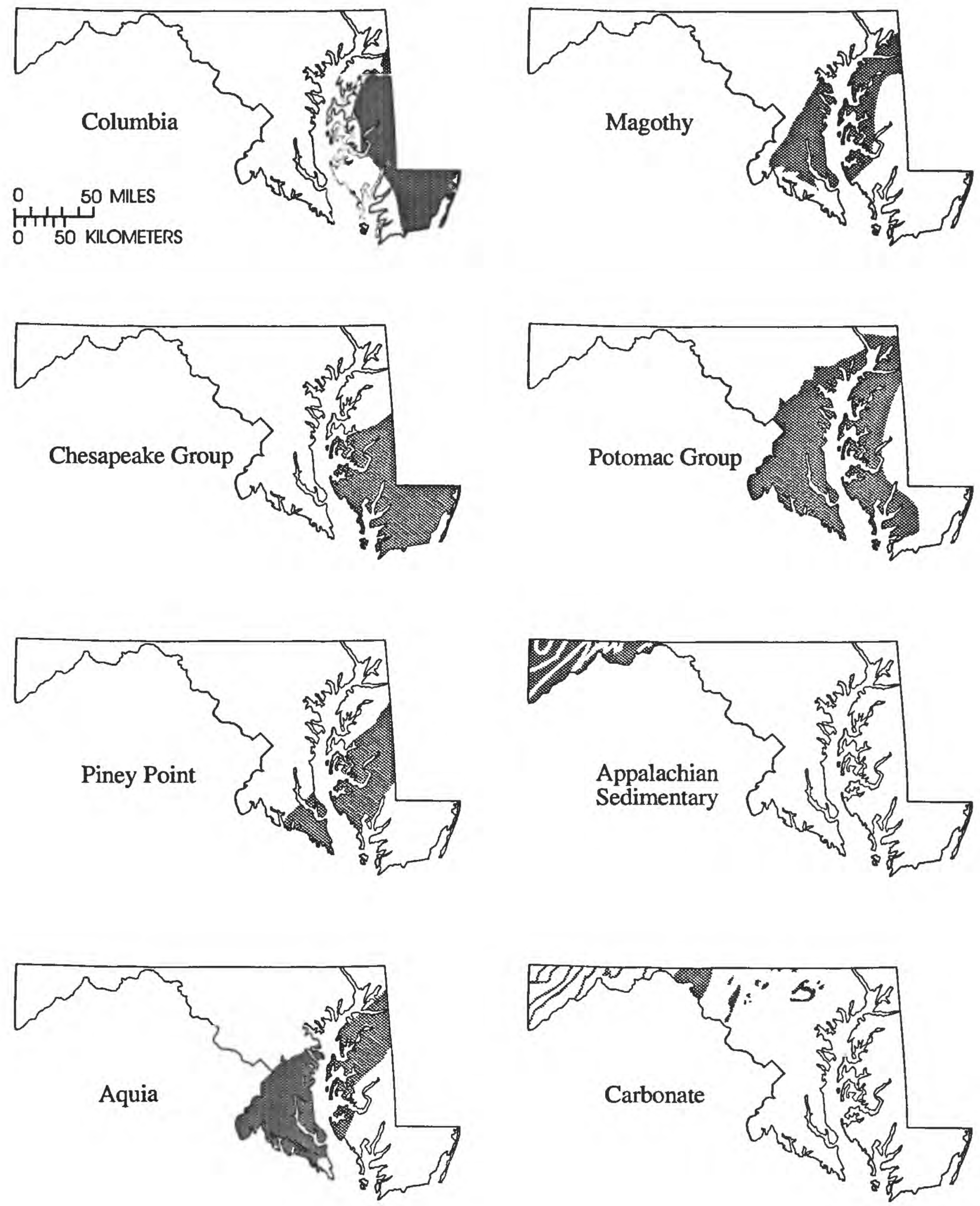

Figure 6. Ground-water withdrawals in Maryland, by principal aquifers, 1990-91.--Continued 
Table 2.--Population and water use in Maryland, 1990-91

[Population data rounded to three significant figures and may not add to totals because of independent rounding. Percentages rounded to two significant figures]

\begin{tabular}{|c|c|c|}
\hline & 1990 & 1991 \\
\hline Total population: & $4,780,000$ & $4,830,000$ \\
\hline Population served by public-supply systems & $3,940,000$ & $3,970,000$ \\
\hline Percentage of population served & 82 & 82 \\
\hline Population served by self-supplied systems & 843,000 & 860,000 \\
\hline Percentage of population self-supplied & 18 & 18 \\
\hline \multicolumn{3}{|l|}{ Surface-water supply: } \\
\hline Percentage of total population served by surface water & 69 & 69 \\
\hline Number served by public-supply systems & $3,290,000$ & $3,310,000$ \\
\hline Percentage of total population & 69 & 69 \\
\hline Number served by self-supplied systems & 0 & 0 \\
\hline Percentage of total population & 0 & 0 \\
\hline \multicolumn{3}{|l|}{ Ground-water supply: } \\
\hline Percentage of total population served by ground water & 31 & 31 \\
\hline Number served by public-supply systems & 645,000 & 657,000 \\
\hline Percentage of total population & 13 & 14 \\
\hline Number served by self-supplied systems & 843,000 & 860,000 \\
\hline Percentage of total population & 18 & 18 \\
\hline
\end{tabular}

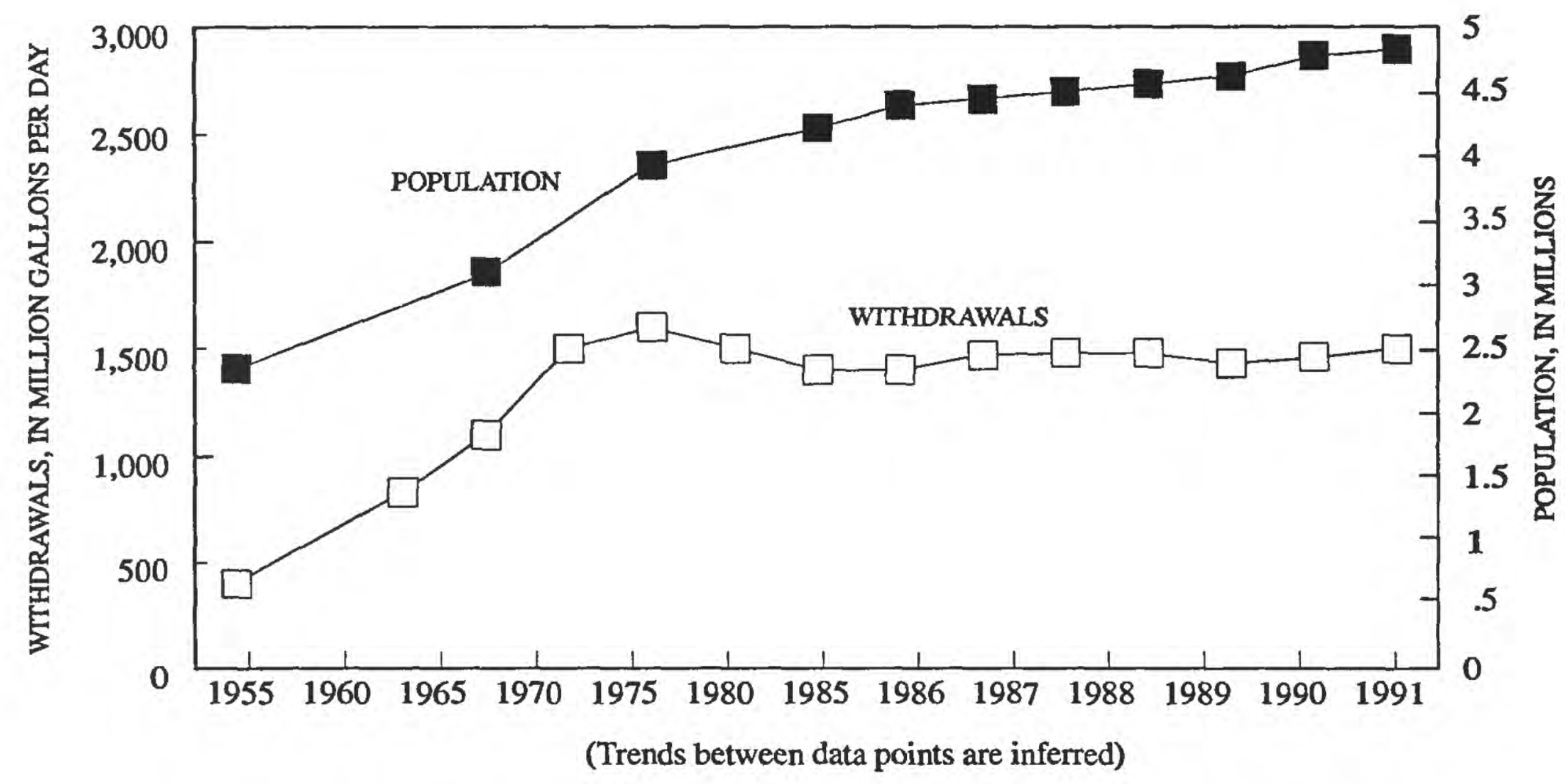

Sources: MacKichan, 1951; MacKichan and Kammerer, 1957; MacKichan and Kammerer, 1961; Murray, 1968; Murray and Reeves, 1972; Murray and Reeves, 1977; Solley and others, 1983; Solley and others, 1988; Solley and others, 1993; Maryland W ater Resources Administration water-use data base; and data compiled from the Maryland Department of State Planning.

Figure 7. Population and freshwater withdrawals in Maryland, 1950-91. 


\section{Mining}

Mining is a major economic activity in Maryland. The mineral resources extracted are those primarily used for building materials and fuels and include stone, sand, gravel, and bituminous coal. Water withdrawn in mining operations is primarily used for dewatering and washing. During 1990, $28 \mathrm{Mgal} / \mathrm{d}$ of freshwater was withdrawn for mining purposes (table 8a). Of that amount, $7.50 \mathrm{Mgal} / \mathrm{d}$ was from surfacewater sources and $20.5 \mathrm{Mgal} / \mathrm{d}$ was from ground-water sources. An additional 21.3 $\mathrm{Mgal} / \mathrm{d}$ of brackish or saline surface water was withdrawn, of which about $20.6 \mathrm{Mgal} / \mathrm{d}$ was for dredging operations. Total freshwater withdrawals for mining during 1991 were 25.3 $\mathrm{Mgal} / \mathrm{d}$ (table $8 \mathrm{~b}$ ). Of that amount, $7.76 \mathrm{Mgal} / \mathrm{d}$ was from surface-water sources and $17.5 \mathrm{Mgal} / \mathrm{d}$ was from ground-water sources. Brackish or saline surface-water withdrawals decreased 82 percent in 1991 to $3.77 \mathrm{Mgal} / \mathrm{d}$ due mainly to reduced dredging operations.

\section{Thermoelectric Power}

Fourteen thermoelectric power plants operate in Maryland; 13 are fossil-fueled and 1 is nuclear-fueled. The demand for electricity and consequently, the amount of water used by power plants, is influenced by various economic, demographic and technological factors such as appliance holdings, weather, household size, income, and the price of electricity. In general, electricity demand is expected to increase in Maryland (Maryland Power Plant Research Program, 1993).

Freshwater use by power plants during 1990 was $421 \mathrm{Mgal} / \mathrm{d}$, of which about $419 \mathrm{Mgal} / \mathrm{d}$ was from surface-water sources and $1.85 \mathrm{Mgal} / \mathrm{d}$ was from ground-water sources (table $9 a$ ). In addition, $4,550 \mathrm{Mgal} / \mathrm{d}$ of saline surface water was used by the plants for cooling condensers, of which more than 98 percent was returned to the water source. During 1991, thermoelectric power plants used about $416 \mathrm{Mgal} / \mathrm{d}$ of freshwater, of which about $414 \mathrm{Mgal} / \mathrm{d}$ was from surface-water sources and $1.65 \mathrm{Mgal} / \mathrm{d}$ was from ground-water sources (table $9 \mathrm{~b}$ ). Larger quantities of saline surface water $(5,760 \mathrm{Mgal} / \mathrm{d})$ were used for cooling condensers during 1991 than in 1990.

\section{Hydroelectric Power}

Water used for the generation of electricity by hydroelectric power plants is discussed here but the quantities of water used are not included in the freshwater totals because this use is considered an "instream" water use--that is, water use takes place within the stream channel at the dam, where turbine generators are driven by the falling water. Twelve plants are currently producing or are licensed to produce hydroelectric power in Maryland (Weisberg and Rose, 1985, p. 1 ), the largest of which is in Harford County.

During 1990, about 25,900 Mgal/d of freshwater passed through these plants for the production of electricity (table 10a); during 1991, the amount decreased to $21,900 \mathrm{Mgal} / \mathrm{d}$ (table 10b). Although the amount of water diverted through some plants is considerable, consumptive use is negligible, because water is not withdrawn from the stream or incorporated into a product. Any consumption is by evaporation during the generation process and from storage reservoirs and this quantity is unknown.

\section{Livestock}

During 1990 and 1991, an estimated 10.4 $\mathrm{Mgal} / \mathrm{d}$ of freshwater was used for livestock activities, mainly livestock watering and feedlot and dairy operations; $2.44 \mathrm{Mgal} / \mathrm{d}$ was from surface-water sources and $7.95 \mathrm{Mgal} / \mathrm{d}$ was from ground-water sources (table 11). The major types of livestock raised in Maryland are poultry, cattle, dairy cows, hogs, and sheep. The four counties (Dorchester, Somerset, Wicomico, and Worcester) of the lower Eastern Shore account for about 30 percent of total agricultural revenue in the State, because this area is one of the Nation's leading producers of broiler chickens (Maryland Department of Agriculture, 1990b).

\section{Irrigation}

The amount of water used for irrigation can vary greatly by year and among users during a particular year. In addition to differences in soils and rainfall distribution, other factors including type of crop or turf grown, timing and length of planting and growing seasons, and watering schedule affect the amount of water used for irrigation (Brodie and others, 1984, p. 7). 
Freshwater use for irrigating farm crops; commercial, municipal, and institutional lawns and parks; golf courses; and nursery plants was about $29.1 \mathrm{Mgal} / \mathrm{d}$ during 1990 (table 12a). Of this amount, $22.8 \mathrm{Mgal} / \mathrm{d}$ was used for irrigating crops including corn, soybeans, tobacco, grains, tomatoes, and melons. In addition, $2.20 \mathrm{Mgal} / \mathrm{d}$ of brackish surface water was used for farm irrigation. Brackish water is too saline to be potable, but is less saline than seawater--that is, total dissolved solids (TDS) concentrations range from about 1,000 to $20,000 \mathrm{mg}$ / $\mathrm{L}$; the TDS concentrations in seawater are about $35,000 \mathrm{mg} / \mathrm{L}$ (Drever, 1982, p. 12).

About 70,000 acres of cropland in Maryland were irrigated in the State during 1990, of which about 63,500 acres or 90 percent were in the eight counties east of Chesapeake Bay (fig. 1). During 1990 , about $9.95 \mathrm{Mgal} / \mathrm{d}$ of fresh surface water was used to irrigate about 24,700 acres and 19.2 $\mathrm{Mgal} / \mathrm{d}$ of ground water was used to irrigate about 38,900 acres.

During 1991, total freshwater used for irrigation increased to $50.4 \mathrm{Mgal} / \mathrm{d}$ (table 12b), of which $41.1 \mathrm{Mgal} / \mathrm{d}$ was used for irrigating farm crops. More land (about 71,700 acres) was irrigated during 1991 than during 1990. About 17.5 $\mathrm{Mgal} / \mathrm{d}$ of fresh surface water was used to irrigate about 25,100 acres and $32.8 \mathrm{Mgal} / \mathrm{d}$ of fresh ground water was used to irrigate about 39,600 acres. In addition, about $4.78 \mathrm{Mgal} / \mathrm{d}$ of brackish surface water was used for irrigating crops.

The county with the largest total irrigated acreage in the State was Caroline County--19,700 acres during 1990 and 20,100 acres during 1991 (about 28 percent of total irrigated land). The largest freshwater withdrawals for irrigation were in Dorchester County, with $7.86 \mathrm{Mgal} / \mathrm{d}$ during 1990 and $12.05 \mathrm{Mgal} / \mathrm{d}$ during 1991.

\section{Aquaculture}

Aquaculture, also known as fish farming or fish culture, is the controlled production of finfish, shellfish, and aquatic plants in fresh and saline water (Maryland Department of Agriculture, 1990a). In Maryland, aquaculture includes production of ornamental fish, oysters, soft-shell crabs, crawfish, hybrid striped bass, catfish, tilapia, trout, aquatic plants, and other aquatic species such as perch and sturgeon.
During 1990, about 9.37 Mgal/d of freshwater was withdrawn for aquaculture in the State, of which $4.84 \mathrm{Mgal} / \mathrm{d}$ was from surfacewater sources and $4.53 \mathrm{Mgal} / \mathrm{d}$ was from ground-water sources (table 13a). In addition, $9.58 \mathrm{Mgal} / \mathrm{d}$ of saline surface water was used for this purpose. Freshwater withdrawals for aquaculture increased during 1991 to $11.6 \mathrm{Mgal} / \mathrm{d}$, of which $6.56 \mathrm{Mgal} / \mathrm{d}$ was from surface-water sources and $5.00 \mathrm{Mgal} / \mathrm{d}$ was from groundwater sources (table 13b). Use of saline surface water also increased during 1991 to $12.5 \mathrm{Mgal} / \mathrm{d}$.

\section{SUMMARY}

During 1990, about 1,460 Mgal/d of freshwater was withdrawn from surface-water and ground-water sources in Maryland, compared to about $1,500 \mathrm{Mgal} / \mathrm{d}$ withdrawn during 1991 . About 1,210 Mgal /d (83 percent) during 1990 and $1,250 \mathrm{Mgal} / \mathrm{d}$ (84 percent) during 1991 were used in the State. About $248 \mathrm{Mgal} / \mathrm{d}$ (17 percent) during 1990 and $249 \mathrm{Mgal} / \mathrm{d}$ (16 percent) during 1991 were transferred to surrounding States and the District of Columbia for water supply. About $7.5 \mathrm{Mgal} / \mathrm{d}$ of freshwater during 1990 and 6.6 $\mathrm{Mgal} / \mathrm{d}$ during 1991 were imported from bordering States for use in Maryland.

Most freshwater withdrawals (about 1,220 $\mathrm{Mgal} / \mathrm{d}$ during 1990 and 1,250 Mgal/d during 1991 or 83 percent of total freshwater withdrawals) were from surface-water sources. The largest surface-water withdrawals, more than $100 \mathrm{Mgal} / \mathrm{d}$, were in Montgomery and Baltimore Counties. The reservoirs and rivers in these counties provide water sources for public suppliers that serve the Baltimore City and District of Columbia metropolitan areas. Most fresh surface water (about $870 \mathrm{Mgal} / \mathrm{d}$ during 1990 and $875 \mathrm{Mgal} / \mathrm{d}$ during 1991 or more than 70 percent of total surface-water withdrawals) was withdrawn and used in the Potomac drainage basin, whereas most ground water (about $170 \mathrm{Mgal} / \mathrm{d}$ during 1990 and $184 \mathrm{Mgal} / \mathrm{d}$ during 1991) was withdrawn and used in the Upper Chesapeake drainage basin. The Potomac Group aquifers were the largest source of ground water (26.6 percent of total ground-water withdrawals) each year.

The population of Maryland served by public water-supply systems increased slightly from 3.94 million during 1990 to 3.97 million during 
1991 (82 percent of the total population). In addition, during the peak tourist season (from May to September), the Ocean City water-supply system served approximately 268,000 more individuals than the base population of about 12,000. During 1990-91, surface water was used by about 69 percent of the State's population and ground water was used by the remaining 31 percent.

Ten water-use categories represent the major demands on the surface-water and ground-water resources of the State during 199091: Public supply, domestic, commercial, industrial, mining, thermoelectric power, hydroelectric power, livestock, irrigation, and aquaculture. Freshwater withdrawals for public supply, self-supplied domestic use, aquaculture, and irrigation increased during 1990-91, whereas withdrawals for commercial, industrial, thermo-electric power, and mining uses decreased.

Public-supply systems withdrew the largest quantity of water in the State $(798 \mathrm{Mgal} / \mathrm{d}$ during 1990 and $826 \mathrm{Mgal} / \mathrm{d}$ during 1991) during 1990-91. This water was delivered for a variety of uses including domestic, commercial, and industrial uses. The largest user of surface water for public supply was Baltimore City. During 1990 , about $135 \mathrm{Mgal} / \mathrm{d}$ was withdrawn for use by the City compared to about $127 \mathrm{Mgal} / \mathrm{d}$ during 1991.

Domestic water use increased from about $484 \mathrm{Mgal} / \mathrm{d}$ during 1990 to $490 \mathrm{Mgal} / \mathrm{d}$ during 1991. About $414 \mathrm{Mgal} / \mathrm{d}$ during 1990 and 420 $\mathrm{Mgal} / \mathrm{d}$ during 1991 were received from public suppliers and about $69.9 \mathrm{Mgal} / \mathrm{d}$ during 1990 and $71.4 \mathrm{Mgal} / \mathrm{d}$ during 1991 were self-supplied. All self-supplied domestic water withdrawals were from ground-water sources.

Total commercial use during 1990 was 113 $\mathrm{Mgal} / \mathrm{d}$, of which about $87.1 \mathrm{Mgal} / \mathrm{d}$ was provided by public suppliers and about 25.8 $\mathrm{Mgal} / \mathrm{d}$ was self-supplied. During 1991, total commercial use decreased to $112 \mathrm{Mgal} / \mathrm{d}$, of which about $86.8 \mathrm{Mgal} / \mathrm{d}$ was provided by public suppliers and about $25.1 \mathrm{Mgal} / \mathrm{d}$ was selfsupplied.

Fresh surface-water and ground-water use by industries decreased from $123 \mathrm{Mgal} / \mathrm{d}$ during
1990 to $116 \mathrm{Mgal} / \mathrm{d}$ during 1991. About 70.1 $\mathrm{Mgal} / \mathrm{d}$ during 1990 and $67.2 \mathrm{Mgal} / \mathrm{d}$ during 1991 were self-supplied. The remaining water used was delivered by public suppliers. Industries also used saline surface water-- $379 \mathrm{Mgal} / \mathrm{d}$ during 1990 and $312 \mathrm{Mgal} / \mathrm{d}$ during 1991. About $62.5 \mathrm{Mgal} / \mathrm{d}$ of reclaimed wastewater was used for industrial purposes each year.

Fresh surface-water and ground-water use for mining decreased from $28 \mathrm{Mgal} / \mathrm{d}$ during 1990 to $25.3 \mathrm{Mgal} / \mathrm{d}$ during 1991. About 21.3 $\mathrm{Mgal} / \mathrm{d}$ during 1990 and $3.77 \mathrm{Mgal} / \mathrm{d}$ during 1991 of brackish or saline surface water were withdrawn, primarily for dredging operations.

Fresh surface-water and ground-water withdrawals for thermoelectric power decreased from $421 \mathrm{Mgal} / \mathrm{d}$ during 1990 to $416 \mathrm{Mgal} / \mathrm{d}$ during 1991. Larger quantities of saline surface water were used for cooling purposes during $1991(5,760 \mathrm{Mgal} / \mathrm{d})$ than during $1990(4,550$ $\mathrm{Mgal} / \mathrm{d}$ ).

Fresh surface-water use for hydroelectric power decreased from $25,900 \mathrm{Mgal} / \mathrm{d}$ during 1990 to 21,900 Mgal/d during 1991. Although the amount of water diverted through some plants was considerable, the amount consumed was negligible.

Fresh surface-water and ground-water use for livestock was about $10.4 \mathrm{Mgal} / \mathrm{d}$ during each year of the 2-year period. About $2.44 \mathrm{Mgal} / \mathrm{d}$ was from surface-water sources and 7.95 Mgal/d was from ground-water sources.

Fresh surface-water and ground-water use for irrigation increased from $29.1 \mathrm{Mgal} / \mathrm{d}$ during 1990 to $50.4 \mathrm{Mgal} / \mathrm{d}$ during 1991. Most of the water (22.8 Mgal /d during 1990 and 41.1 $\mathrm{Mgal} / \mathrm{d}$ during 1991) was used for irrigating farm crops.

Fresh surface-water and ground-water withdrawals for aquaculture increased from 9.37 Mgal/d during 1990 to $11.6 \mathrm{Mgal} / \mathrm{d}$ during 1991 . Saline surface-water withdrawals for aquaculture also increased from $9.58 \mathrm{Mgal} / \mathrm{d}$ during 1990 to $12.5 \mathrm{Mgal} / \mathrm{d}$ during 1991. 
Andrews, Miller \& Assoc., Inc., 1990, Comprehensive water \& sewerage plan for Worcester County, Maryland: Andrews, Miller \& Assoc., Inc., Cambridge, Maryland, $166 \mathrm{p}$.

Booth, Nan, 1984, Maryland residential water statistics: University of Maryland, Cooperative Extension Service Fact Sheet 383, College Park, Maryland, 2 p.

Brodie, H.L., Carr, L.E., Russek, Estelle, and Stewart, L.E., 1984, A survey of agricultural irrigation in Maryland--1982: University of Maryland, Cooperative Extension Service, College Park, Maryland, $51 \mathrm{p}$.

Carr, L.E., 1991, The 1990 Maryland irrigation survey: University of Maryland, College Park, Maryland, 7 p.

Drever, J.I., 1982, The geochemistry of natural waters: Prentice-Hall, Inc., Englewood Cliffs, New Jersey, $388 \mathrm{p}$.

Di Lisio, J.E., 1983, Maryland, a geography: Boulder, Colorado, Westview Press, 233 p.

Hem, J.D., 1985, Study and interpretation of the chemical characteristics of natural water: U.S. Geological Survey Water-Supply Paper 2254, 263 p.

MacKichan, K.A., 1951, Estimated use of water in the United States-1950: U.S. Geological Survey Circular $115,13 \mathrm{p}$.

MacKichan, K.A., and Kammerer, J.C., 1957, Estimated use of water in the United States, 1955: U.S. Geological Survey Circular 398, 18 p. 1961, Estimated use of water in the United States in 1960: U.S. Geological Survey Circular 456, 44 p.

Maryland Department of Agriculture, 1990a, Aquaculture in Maryland: Information Sheet, Annapolis, Maryland, $2 \mathrm{p}$.

1990b, Maryland agricultural statistics--Summary for 1990: Maryland Department of Agriculture, Annapolis, Maryland, $53 \mathrm{p}$.

Maryland Department of State Planning, 1981, Maryland population data--State, county, minor civil division and municipal trends through 1980: Maryland Department of State Planning, Office of Planning Data, Baltimore, Maryland, 253 p.

1990, Maryland Office of Planning population projections: Maryland Department of State Planning, Office of Planning, Report 5A-Total (Revisions, June 1990), Baltimore, Maryland, 75 p.

Maryland Water Resources Administration, 1987, Maryland water withdrawal and use report for 1985: Maryland Department of Natural Resources, Annapolis, Maryland, 40 p.
Murray, C.R., 1968, Estimated use of water in the United States in 1965: U.S. Geological Survey Circular 556, $53 \mathrm{p}$.

Murray, C.R., and Reeves, E.B., 1972, Estimated use of water in the United States in 1970: U.S. Geological Survey Circular 675, 37 p. 1977, Estimated use of water in the United States in 1975: U.S. Geological Survey Circular 765, 39 p.

Maryland Power Plant Research Program, 1993, Maryland power plants and the environment; a review of impacts of power plants and transmission lines on Maryland's natural resources; supporting materials: Maryland Department of Natural Resources, Annapolis, Maryland, $75 \mathrm{p}$.

Solley, W.B., Chase, E.B., and Mann, W.B., 1983, Estimated use of water in the United States in 1980: U.S. Geological Survey Circular 1001, 82 p.

Solley, W.B., Merk, C.F., and Pierce, R.R., 1988, Estimated use of water in the United States in 1985: U.S. Geological Survey Circular 1004, 82 p.

Solley, W.B., Pierce, R.R., and Perlman, H.A., 1993, Estimated use of water in the United States in 1990: U.S. Geological Survey Circular 1081, 76 p.

U.S. Department of Commerce, 1988, 1987 census of agriculture, advance county reports: U.S. Bureau of the Census, Government Printing Office, Washington, D.C., (23) 2-page sheets, by county. 1990a, 1990 census of population and housing-Summary population and housing characteristics-Maryland: U.S. Bureau of the Census, Government Printing Office, 1990 CPH-1-22, $117 \mathrm{p}$.

$1990 \mathrm{~b}, 1990$ census of population and housingSummary social, economic, and housing characteristics--Maryland: U.S. Bureau of the Census, Government Printing Office, 1990 CPH-5$22,155 \mathrm{p}$.

U.S. Environmental Protection Agency, 1973, Manual of individual water supply systems: U.S. Government Printing Office, Washington, D.C., 155 p.

U.S. Geological Survey, 1985, National water summary 1984--hydrologic events, selected water-quality trends, and ground-water resources: U.S. Geological Survey Water-Supply Paper 2275, 467 p.

1990, National water summary 1987--hydrologic events and water supply and use: U.S. Geological Survey Water-Supply Paper 2350, 553 p. 
Webb, W.E., and Heidel, S.G., 1970, Extent of brackish water in the tidal rivers of Maryland: Maryland Geological Survey Report of Investigations No. 13, Maryland Geological Survey, Baltimore, Maryland, $46 \mathrm{p}$.

Weisberg, S.B., and Rose, K.A., 1985, Inventory of Maryland dams and assessment of hydropower resources: Martin Marietta Environmental Systems, Columbia, Maryland, $341 \mathrm{p}$.

Wheeler, J.C., 1990, Water withdrawal and use in Maryland, 1986: U.S. Geological Survey Open-File Report 88-714, 30 p.
1991, Water withdrawal and use in Maryland, 1987: U.S. Geological Survey Open-File Report 90$572,32 \mathrm{p}$.

1992, Water withdrawal and use in Maryland, 1988-89: U.S. Geological Survey Water-Resources Report of Investigations $91-4179,40 \mathrm{p}$.

Wheeler, J.C., and Wilde, F.D., 1989, Ground-water use in the Coastal Plain of Maryland, 1900-1980: U.S. Geological Survey Open-File Report 87-540, $173 \mathrm{p}$. 


\section{APPENDIX \\ WATER WITHDRAWAL AND USE DATA FOR MARYLAND, 1990-91}




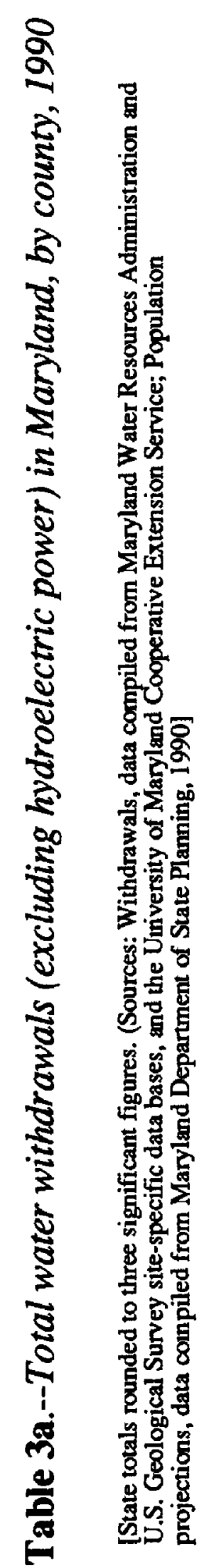

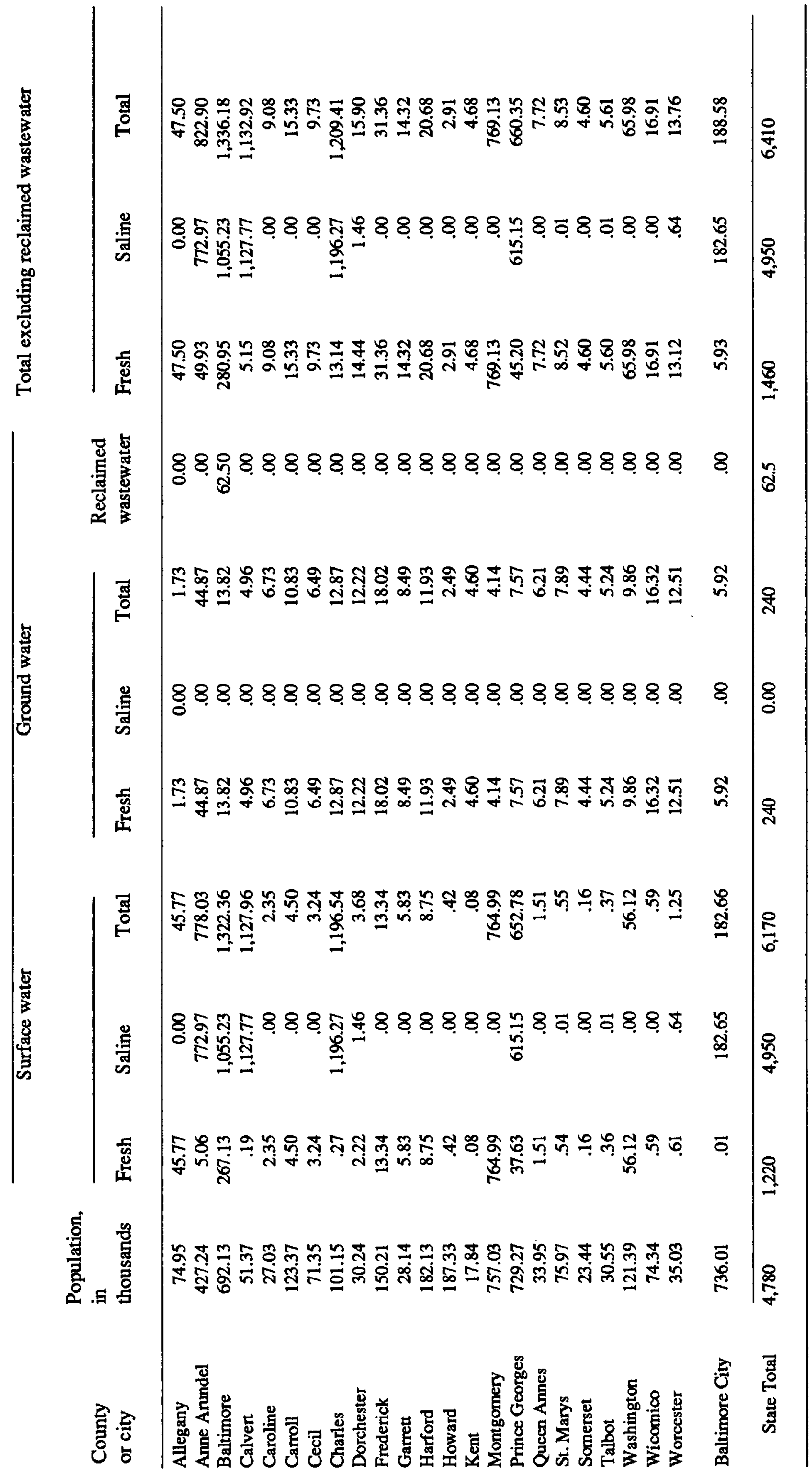




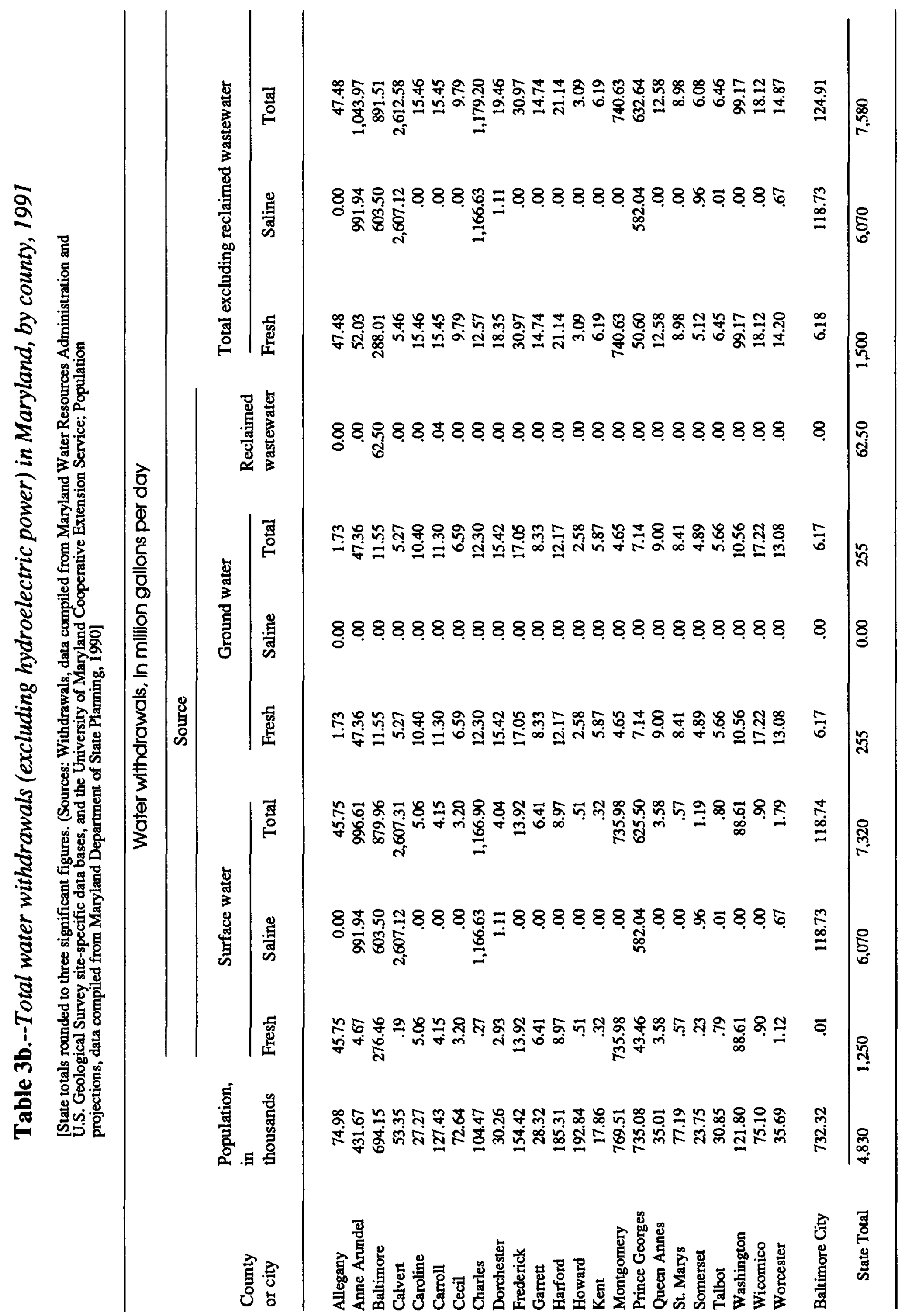




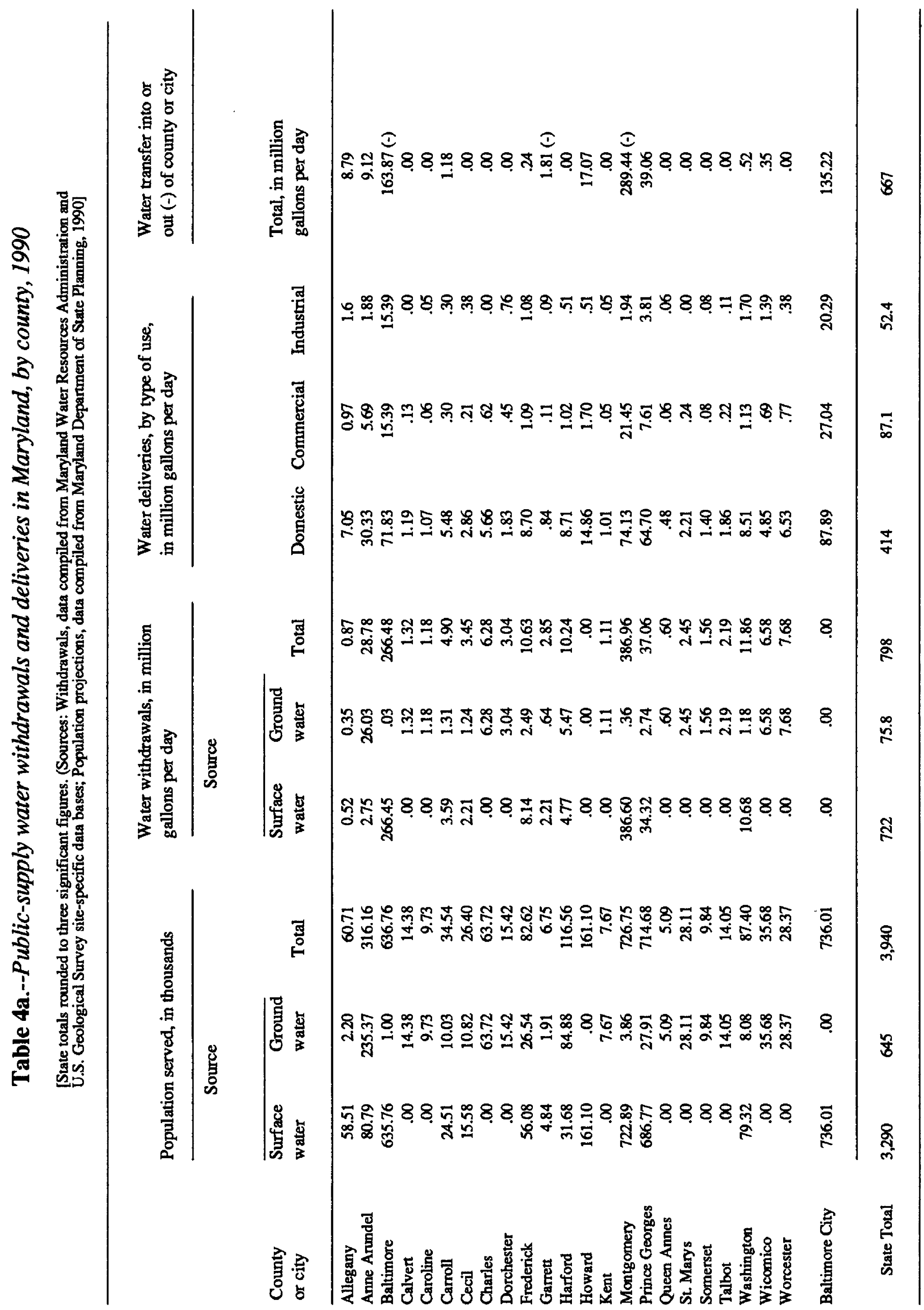




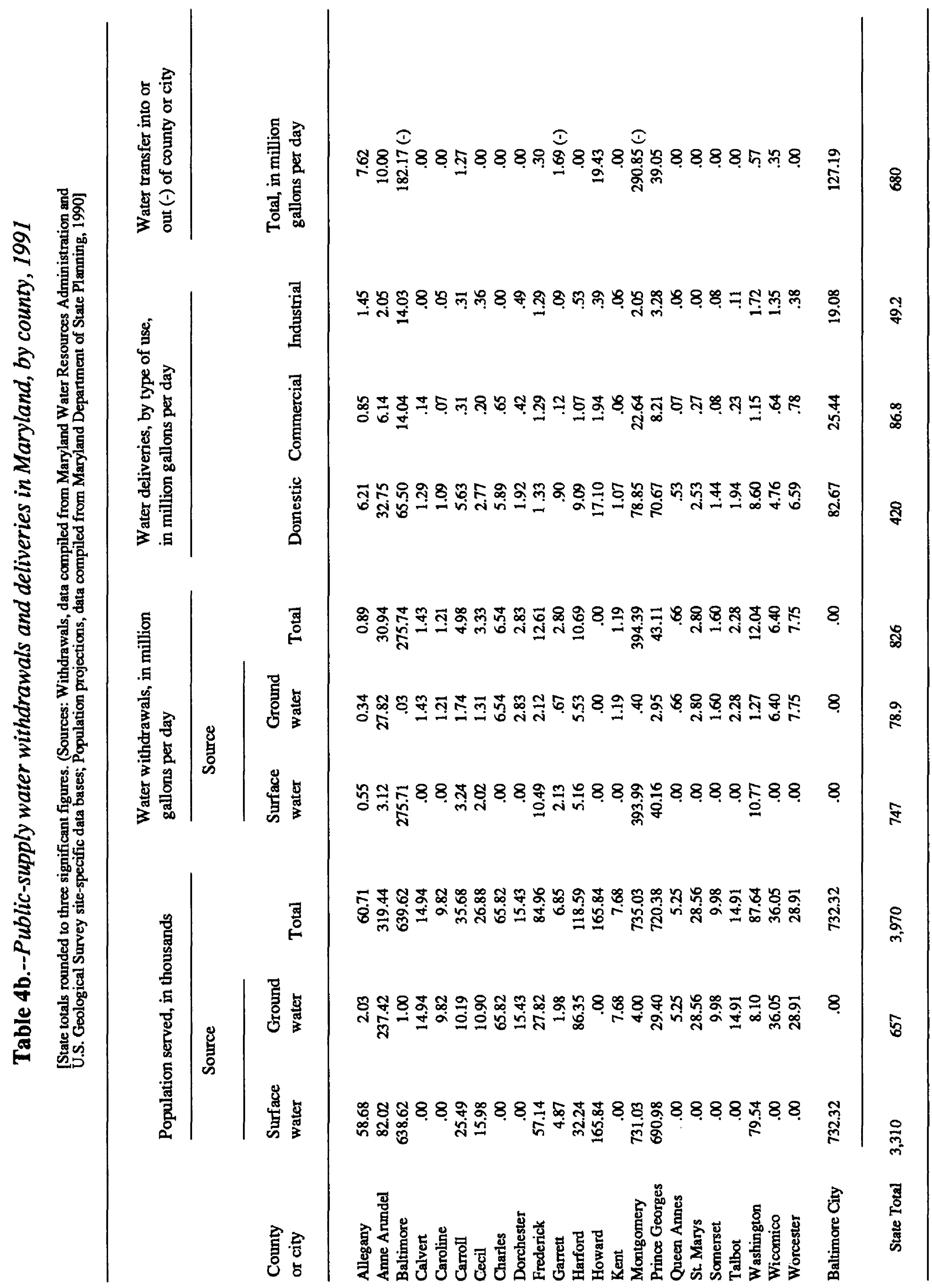


Table 5a.--Domestic water withdrawals (self-supplied) and deliveries from public suppliers in Maryland, by county, 1990

[State totals rounded to three significant figures. (Sources: Withdrawals, estimated using population projection data compiled from Maryland Department of State Planning, 1990, using per capita use of 80 gallons per day; Population projections, data compiled from Maryland Department of State Planning, 1990]

\begin{tabular}{|c|c|c|c|c|c|}
\hline \multirow[b]{2}{*}{$\begin{array}{l}\text { County } \\
\text { or } \\
\text { city }\end{array}$} & \multicolumn{2}{|c|}{ Self-supplled } & \multicolumn{2}{|c|}{ Publlc-supplled } & \multirow{2}{*}{ 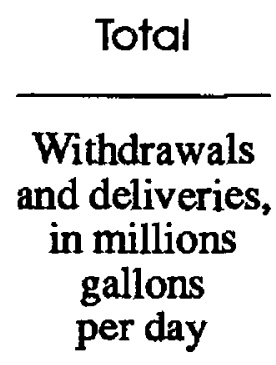 } \\
\hline & $\begin{array}{l}\text { Population, } \\
\text { in thousands }\end{array}$ & $\begin{array}{l}\text { Ground-water } \\
\text { withdrawals, in } \\
\text { million gallons } \\
\text { per day }\end{array}$ & $\begin{array}{l}\text { Population } \\
\text { served, in } \\
\text { thousands }\end{array}$ & $\begin{array}{c}\text { Water } \\
\text { deliveries, } \\
\text { in millions } \\
\text { gallons } \\
\text { per day }\end{array}$ & \\
\hline Allegany & 14.24 & 1.15 & 60.71 & 7.05 & 8.20 \\
\hline Anne Arundel & 111.08 & 9.61 & 316.16 & 30.33 & 39.94 \\
\hline Baltimore & 55.37 & 4.46 & 636.76 & 71.83 & 76.29 \\
\hline Calvert & 36.99 & 3.05 & 14.38 & 1.19 & 4.24 \\
\hline Caroline & 17.30 & 1.44 & 9.73 & 1.07 & 2.51 \\
\hline Carroll & 88.83 & 7.16 & 34.54 & 5.48 & 12.64 \\
\hline Cecil & 44.95 & 3.61 & 26.40 & 2.86 & 6.47 \\
\hline Charles & 37.43 & 3.01 & 63.72 & 5.66 & 8.67 \\
\hline Dorchester & 14.82 & 1.20 & 15.42 & 1.83 & 3.03 \\
\hline Frederick & 67.59 & 5.47 & 82.62 & 8.70 & 14.17 \\
\hline Garrett & 21.39 & 1.71 & 6.75 & .84 & 2.55 \\
\hline Harford & 65.57 & 5.32 & 116.56 & 8.71 & 14.03 \\
\hline Howard & 26.23 & 2.14 & 161.10 & 14.86 & 17.00 \\
\hline Kent & 10.17 & .84 & 7.67 & 1.01 & 1.85 \\
\hline Montgomery & 30.28 & 2.72 & 726.75 & 74.13 & 76.85 \\
\hline Prince Georges & 14.59 & 1.19 & 714.68 & 64.70 & 65.89 \\
\hline Queen Annes & 28.86 & 2.43 & 5.09 & .48 & 2.91 \\
\hline St. Marys & 47.86 & 3.91 & 28.11 & 2.21 & 6.12 \\
\hline Somerset & 13.60 & 1.09 & 9.84 & 1.40 & 2.49 \\
\hline Talbot & 16.50 & 1.43 & 14.05 & 1.86 & 3.29 \\
\hline Washington & 33.99 & 2.74 & 87.40 & 8.51 & 11.25 \\
\hline Wicomico & 38.66 & 3.50 & 35.68 & 4.85 & 8.35 \\
\hline Worcester & 6.66 & .70 & 28.37 & 6.53 & 7.23 \\
\hline Baltimore City & .00 & .00 & 736.01 & 87.89 & 87.89 \\
\hline State Total & 843 & 69.9 & 3,940 & 414 & 484 \\
\hline
\end{tabular}


Table 5b.--Domestic water withdrawals (self-supplied) and deliveries from public suppliers in Maryland, by county, 1991

[State totals rounded to three significant figures. (Sources: Withdrawals, estimated using population projection data compiled from Maryland Department of State Planning, 1990, using per capita use of $\mathbf{8 0}$ gallons per day; Population projections, data compiled from Maryland Departmeut of State Planning, 1990]

\begin{tabular}{|c|c|c|c|c|c|}
\hline \multirow[b]{2}{*}{$\begin{array}{l}\text { County } \\
\text { or } \\
\text { city }\end{array}$} & \multicolumn{2}{|c|}{ Self-supplied } & \multicolumn{2}{|c|}{ Public-supplled } & \multirow{2}{*}{$\begin{array}{c}\text { Total } \\
\text { Withdrawals } \\
\text { and deliveries, } \\
\text { in millions } \\
\text { gallons } \\
\text { per day }\end{array}$} \\
\hline & $\begin{array}{l}\text { Population, } \\
\text { in thousands }\end{array}$ & $\begin{array}{c}\text { Ground-water } \\
\text { withdrawals, in } \\
\text { million gallons } \\
\text { per day }\end{array}$ & $\begin{array}{l}\text { Population } \\
\text { served, in } \\
\text { thousands }\end{array}$ & $\begin{array}{c}\text { Water } \\
\text { deliveries, } \\
\text { in millions } \\
\text { gallons } \\
\text { per dày }\end{array}$ & \\
\hline Allegany & 14.27 & 1.15 & 60.71 & 6.21 & 7.36 \\
\hline Anne Arundel & 112.23 & 9.72 & 319.44 & 32.75 & 42.47 \\
\hline Baltimore & 54.53 & 4.39 & 639.62 & 65.50 & 69.89 \\
\hline Calvert & 38.41 & 3.17 & 14.94 & 1.29 & 4.46 \\
\hline Caroline & 17.45 & 1.45 & 9.82 & 1.09 & 2.54 \\
\hline Carroll & 91.75 & 7.39 & 35.68 & 5.63 & 13.02 \\
\hline Cecil & 45.76 & 3.67 & 26.88 & 2.77 & 6.44 \\
\hline Charles & 38.65 & 3.11 & 65.82 & 5.89 & 9.00 \\
\hline Dorchester & 14.83 & 1.22 & 15.43 & 1.92 & 3.14 \\
\hline Frederick & 69.46 & 5.62 & 84.96 & 10.33 & 15.95 \\
\hline Garrett & 21.47 & 1.72 & 6.85 & .90 & 2.62 \\
\hline Harford & 66.72 & 5.42 & 118.59 & 9.09 & 14.51 \\
\hline Howard & 27.00 & 2.20 & 165.84 & 17.10 & 19.30 \\
\hline Kent & 10.18 & .85 & 7.68 & 1.07 & 1.92 \\
\hline Montgomery & 34.48 & 3.07 & 735.03 & 78.85 & 81.92 \\
\hline Prince Georges & 14.70 & 1.20 & 720.38 & 70.67 & 71.87 \\
\hline Queen Annes & 29.76 & 2.50 & 5.25 & .53 & 3.03 \\
\hline St Marys & 48.63 & 3.97 & 28.56 & 2.53 & 6.50 \\
\hline Somerset & 13.77 & 1.11 & 9.98 & 1.44 & 2.55 \\
\hline Talbot & 15.94 & 1.45 & 14.91 & 1.94 & 3.39 \\
\hline Washington & 34.16 & 2.75 & 87.64 & 8.60 & 11.35 \\
\hline Wicomico & 39.05 & 3.57 & 36.05 & 4.76 & $8.33^{\circ}$ \\
\hline Worcester & 6.78 & .71 & 28.91 & 6.59 & 7.30 \\
\hline Baltimore City & .00 & .00 & 732.32 & 82.67 & 82.67 \\
\hline State Total & 860 & 71.4 & 3,970 & 420 & 490 \\
\hline
\end{tabular}


Table 6a.--Commercial freshwater withdrawals (self-supplied) and deliveries from public suppliers in Maryland, by county, 1990

[State totals rounded to three significant figures. Source: Data compiled from Maryland Water Resources Administration files]

\begin{tabular}{|c|c|c|c|c|c|}
\hline \multirow{4}{*}{$\begin{array}{l}\text { County } \\
\text { or } \\
\text { city }\end{array}$} & \multicolumn{3}{|c|}{ Self-supplied } & \multirow{4}{*}{$\begin{array}{c}\text { Publlc-suppiled } \\
\\
\text { Water } \\
\text { deliveries, } \\
\text { in millions } \\
\text { gallons } \\
\text { per day }\end{array}$} & \multirow{4}{*}{$\begin{array}{c}\text { Total } \\
\\
\text { Withdrawals } \\
\text { and deliveries, } \\
\text { in millions } \\
\text { gallons } \\
\text { per day }\end{array}$} \\
\hline & \multicolumn{3}{|c|}{$\begin{array}{l}\text { Water withdrawals, in million } \\
\text { gallons per day }\end{array}$} & & \\
\hline & \multicolumn{2}{|c|}{ Source } & \multirow[b]{2}{*}{ Total } & & \\
\hline & $\begin{array}{l}\text { Surface } \\
\text { water }\end{array}$ & $\begin{array}{l}\text { Ground } \\
\text { water }\end{array}$ & & & \\
\hline Allegany & 0.03 & 0.16 & 0.19 & 0.97 & 1.16 \\
\hline Anne Anundel & .38 & 6.52 & 6.90 & 5.69 & 12.59 \\
\hline Baltimore & .06 & .54 & .60 & 15.39 & 15.99 \\
\hline Calvert & .01 & .37 & .38 & .13 & .51 \\
\hline Caroline & .00 & .20 & .20 & .06 & .26 \\
\hline Carroll & .46 & .46 & .92 & .30 & 1.22 \\
\hline Cecil & .40 & .54 & .94 & .21 & 1.15 \\
\hline Charles & .00 & 2.78 & 2.78 & .62 & 3.40 \\
\hline Dorchester & .00 & .20 & .20 & .45 & .65 \\
\hline Frederick & .97 & .76 & 1.73 & 1.09 & 2.82 \\
\hline Garrett & .28 & .61 & .89 & .11 & 1.00 \\
\hline Harford & 3.52 & .37 & 3.89 & 1.02 & 4.91 \\
\hline Howard & .04 & .20 & .24 & 1.70 & 1.94 \\
\hline Kent & .00 & .13 & .13 & .05 & .18 \\
\hline Montgomery & .02 & .41 & .43 & 21.45 & 21.88 \\
\hline Prince Georges & .15 & 1.12 & 1.27 & 7.61 & 8.88 \\
\hline Queen Annes & .01 & .58 & .59 & .06 & .65 \\
\hline St. Marys & .00 & 1.46 & 1.46 & .24 & 1.70 \\
\hline Somerset & .00 & .36 & .36 & .08 & .44 \\
\hline Talbot & .00 & .42 & .42 & .22 & .64 \\
\hline Washington & .08 & .21 & .29 & 1.13 & 1.42 \\
\hline Wicomico & .00 & .56 & .56 & .69 & 1.25 \\
\hline Worcester & .00 & .45 & .45 & .77 & 1.22 \\
\hline Baltimore City & .00 & .00 & .00 & 27.04 & 27.04 \\
\hline State Total & 6.41 & 19.4 & 25.8 & 87.1 & 113 \\
\hline
\end{tabular}


Table 6b.--Commercial freshwater withdrawals (self-supplied) and deliveries from public suppliers in Maryland, by county, 1991

[State totals rounded to three significant figures. Source: Data compiled from Maryland Water Resources Administration files]

\begin{tabular}{|c|c|c|c|c|c|}
\hline \multirow{4}{*}{$\begin{array}{l}\text { County } \\
\text { or } \\
\text { city }\end{array}$} & \multicolumn{3}{|c|}{ Self-supplied } & \multirow{4}{*}{$\begin{array}{c}\text { Publlc-supplied } \\
\\
\text { Water } \\
\text { deliveries, } \\
\text { in millions } \\
\text { gallons } \\
\text { per day }\end{array}$} & \multirow{4}{*}{$\begin{array}{c}\text { Totai } \\
\\
\text { Withdrawals } \\
\text { and deliveries } \\
\text { in millions } \\
\text { gallons } \\
\text { per day }\end{array}$} \\
\hline & \multicolumn{3}{|c|}{$\begin{array}{l}\text { Water withdrawals, in million } \\
\text { gallons per day }\end{array}$} & & \\
\hline & \multicolumn{2}{|c|}{ Source } & \multirow[b]{2}{*}{ Total } & & \\
\hline & $\begin{array}{c}\text { Surface } \\
\text { water }\end{array}$ & $\begin{array}{l}\text { Ground } \\
\text { water }\end{array}$ & & & \\
\hline Allegany & 0.03 & 0.16 & 0.19 & 0.85 & 1.04 \\
\hline Anne Arundel & .07 & 7.38 & 7.45 & 6.14 & 13.59 \\
\hline Baltimore & .07 & .56 & .63 & 14.04 & 14.67 \\
\hline Calvert & .01 & .39 & .40 & .14 & .54 \\
\hline Caroline & .00 & .20 & .20 & .07 & .27 \\
\hline Carroll & .43 & .48 & .91 & .31 & 1.22 \\
\hline Cecil & .43 & .56 & .99 & .20 & 1.19 \\
\hline Charles & .00 & 1.92 & 1.92 & .65 & 2.57 \\
\hline Dorchester & .00 & .24 & .24 & .42 & .66 \\
\hline Frederick & .04 & .72 & .76 & 1.29 & 2.05 \\
\hline Garrett & .26 & .63 & .89 & .12 & 1.01 \\
\hline Harford & 3.36 & .40 & 3.76 & 1.07 & 4.83 \\
\hline Howard & .05 & .24 & .29 & 1.94 & 2.23 \\
\hline Kent & .00 & .13 & .13 & .06 & .19 \\
\hline Montgomery & .01 & .43 & .44 & 22.64 & 23.08 \\
\hline Prince Georges & .15 & 1.27 & 1.42 & 8.21 & 9.63 \\
\hline Queen Annes & .01 & .67 & .68 & .07 & .75 \\
\hline St. Marys & .01 & 1.49 & 1.50 & .27 & 1.77 \\
\hline Somerset & .00 & .46 & .46 & .08 & .54 \\
\hline Talbot & .00 & .42 & .42 & .23 & .65 \\
\hline Washington & .10 & .24 & .34 & 1.15 & 1.49 \\
\hline Wicomico & .00 & .59 & .59 & .64 & 1.23 \\
\hline Worcester & .00 & .47 & .47 & .78 & 1.25 \\
\hline Baltimore City & .00 & .00 & .00 & 25.44 & 25.44 \\
\hline State Total & 5.03 & 20.0 & 25.1 & 86.8 & 112 \\
\hline
\end{tabular}




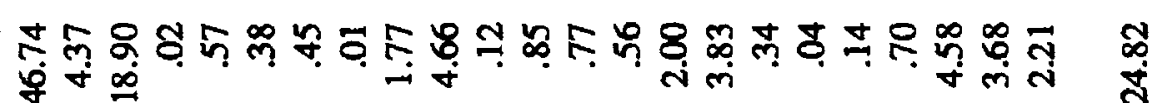

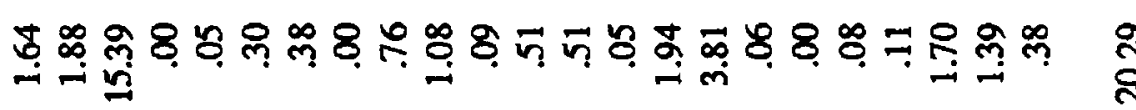

๙్రా

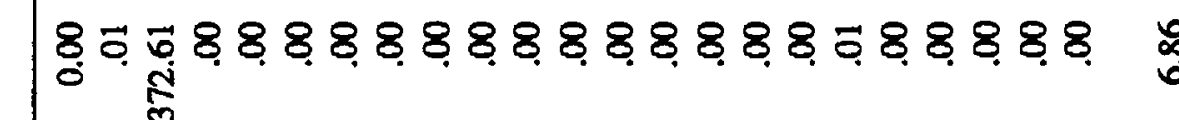

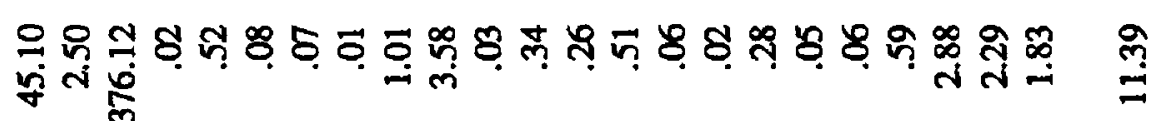

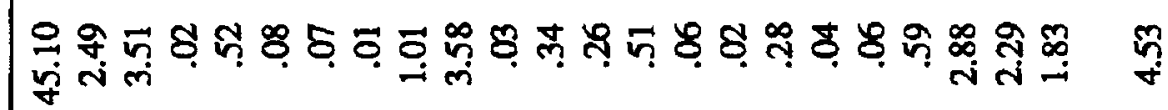

$\overrightarrow{8}$

8.

\%ั้

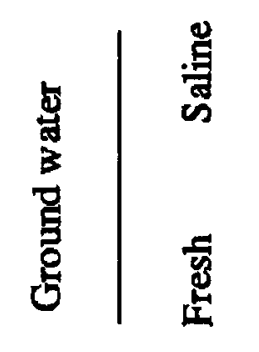

8.8.8.8.8.8.8.8.8.88.8.8.8.8.8. 8.

$\stackrel{8}{0}$

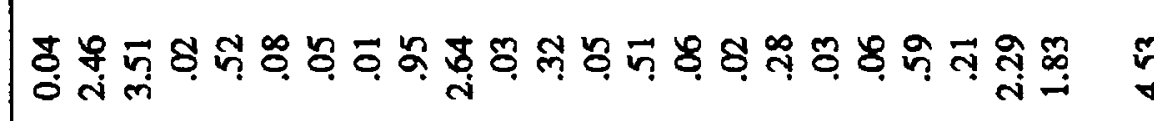

$\vec{i}$

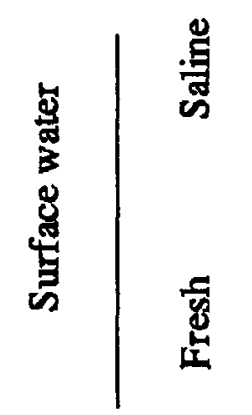

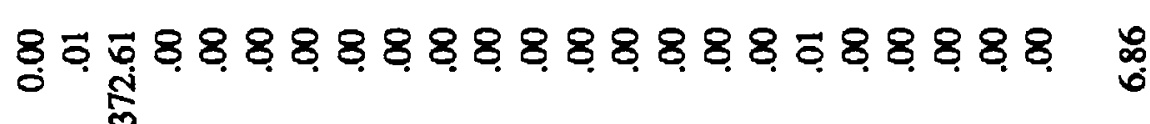

을

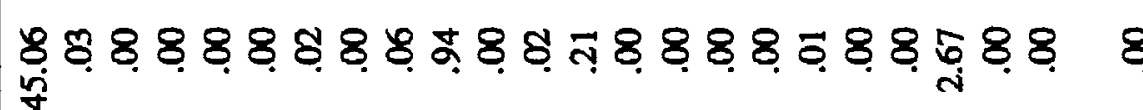

$\stackrel{\circ}{\dot{q}}$

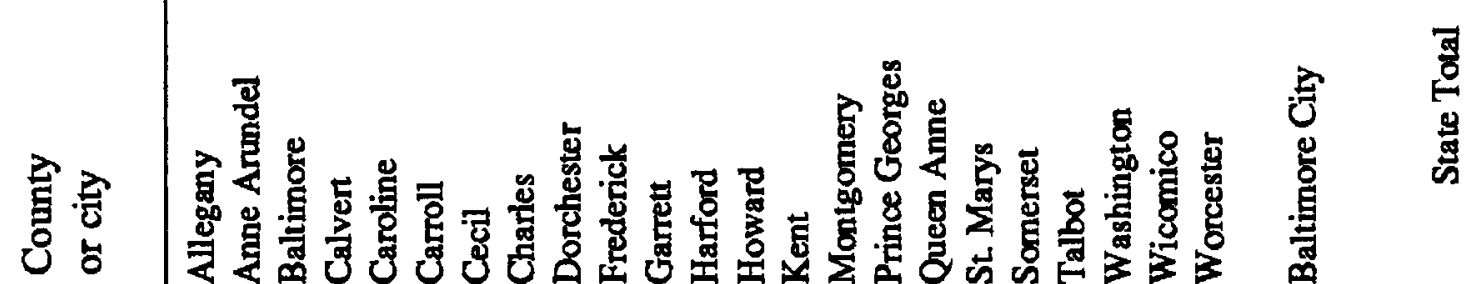




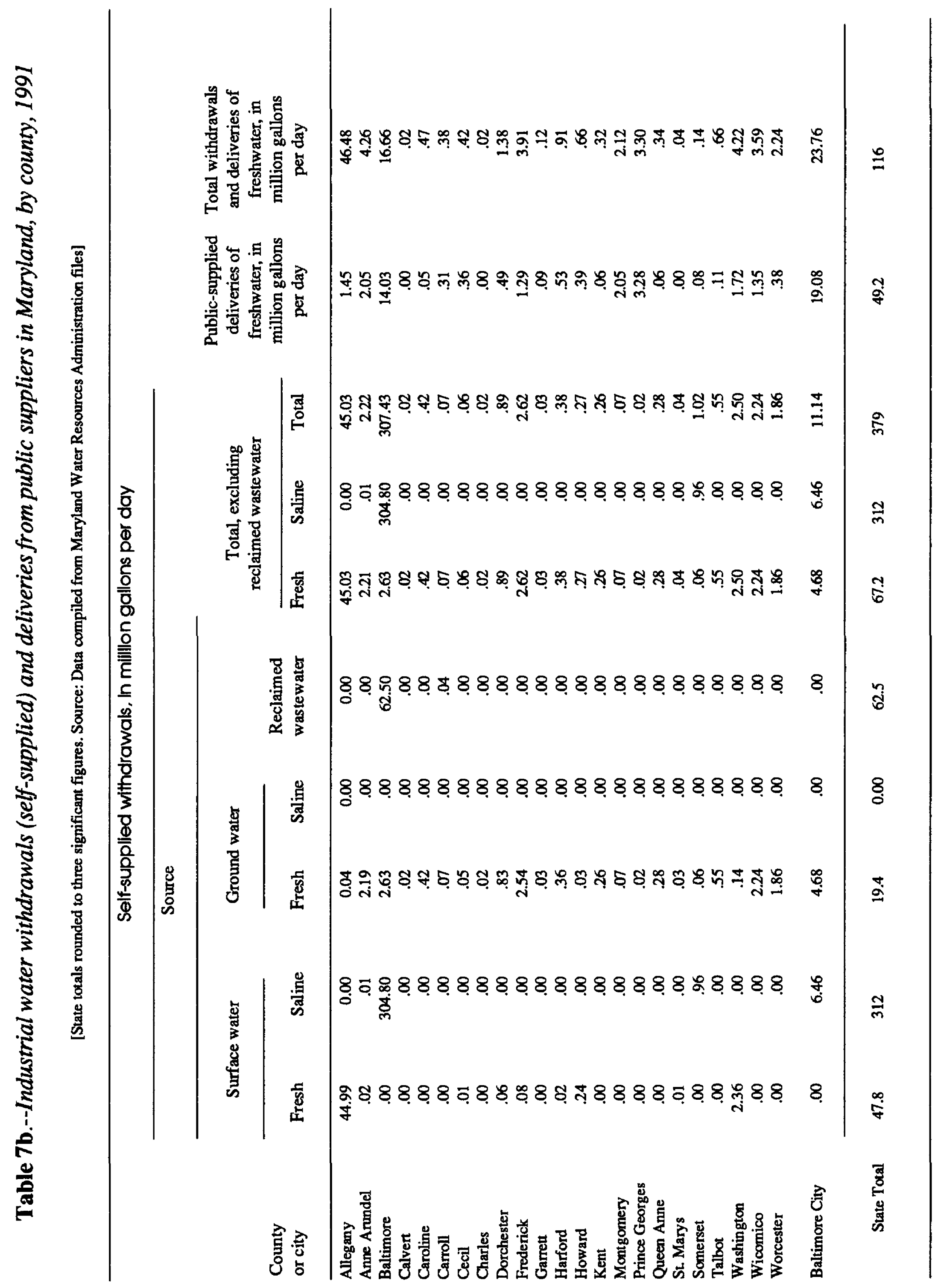




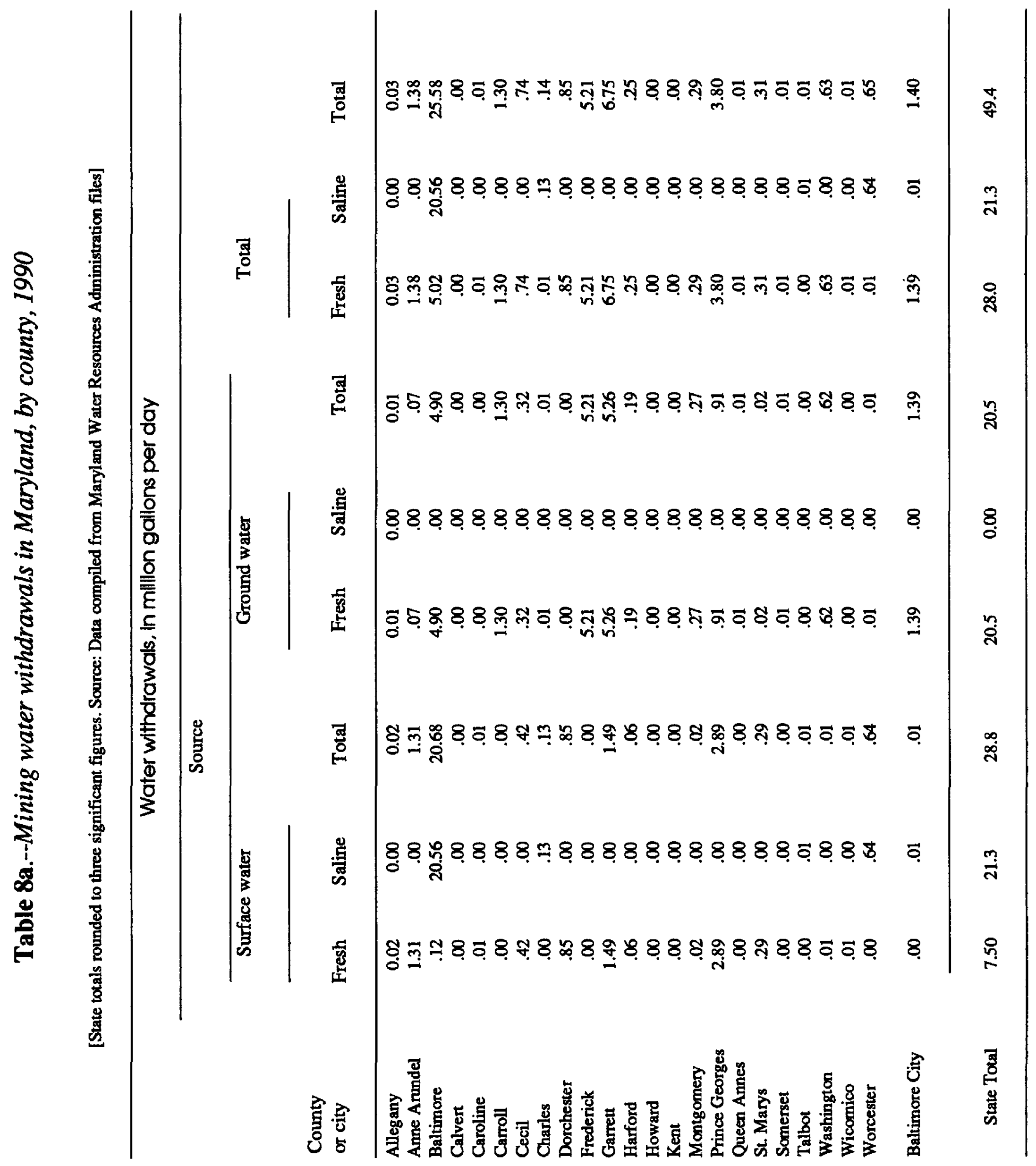




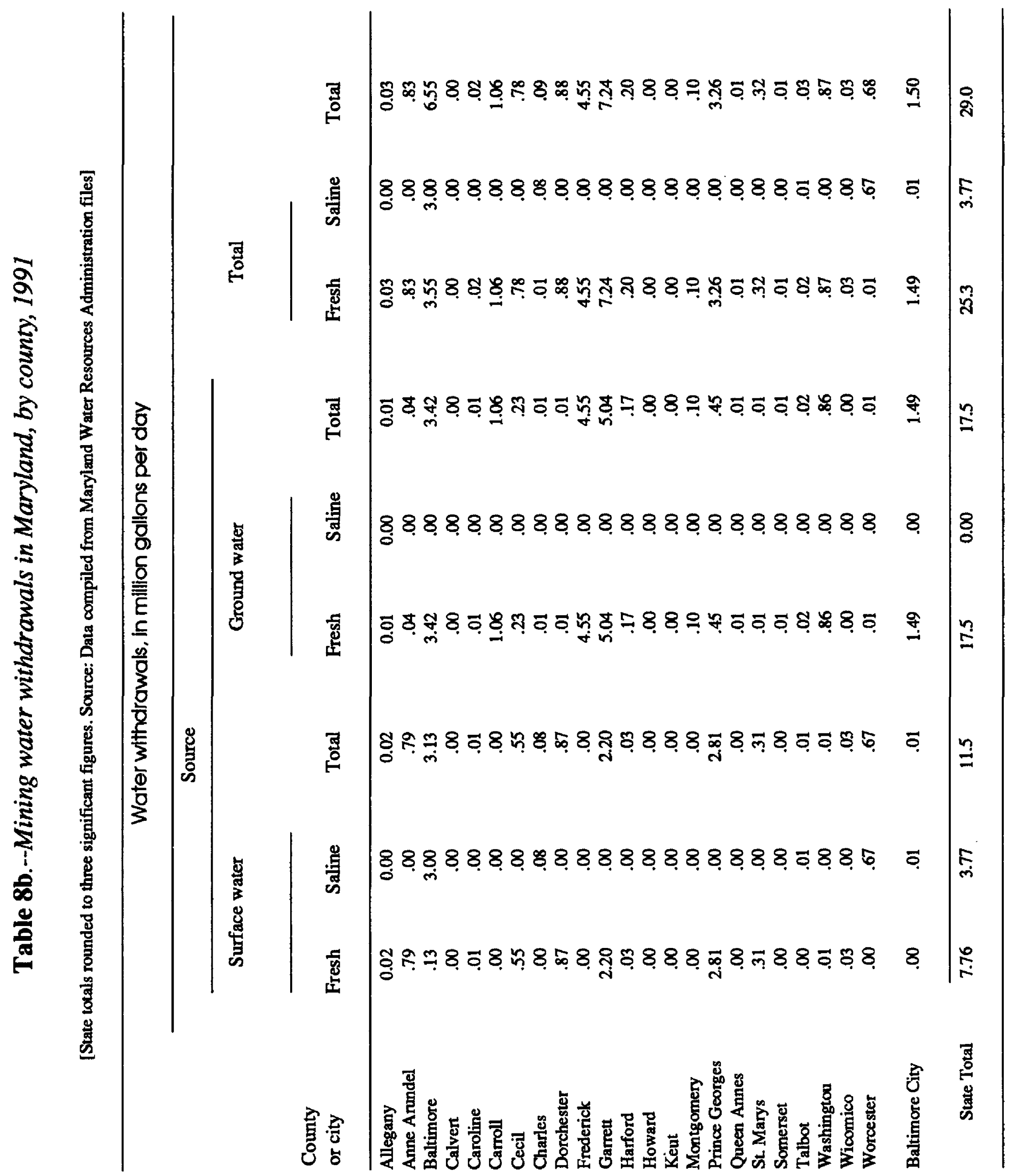




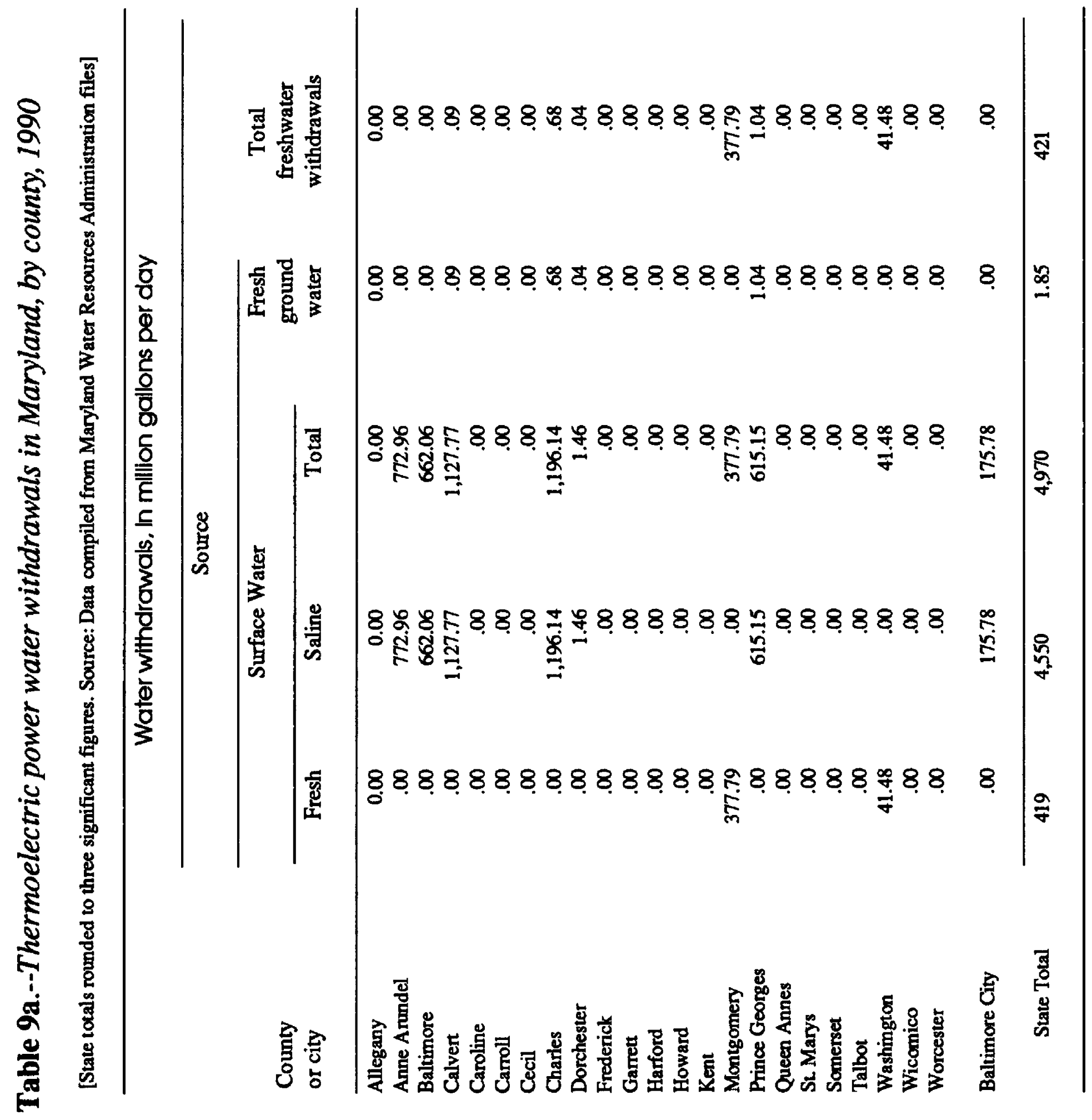




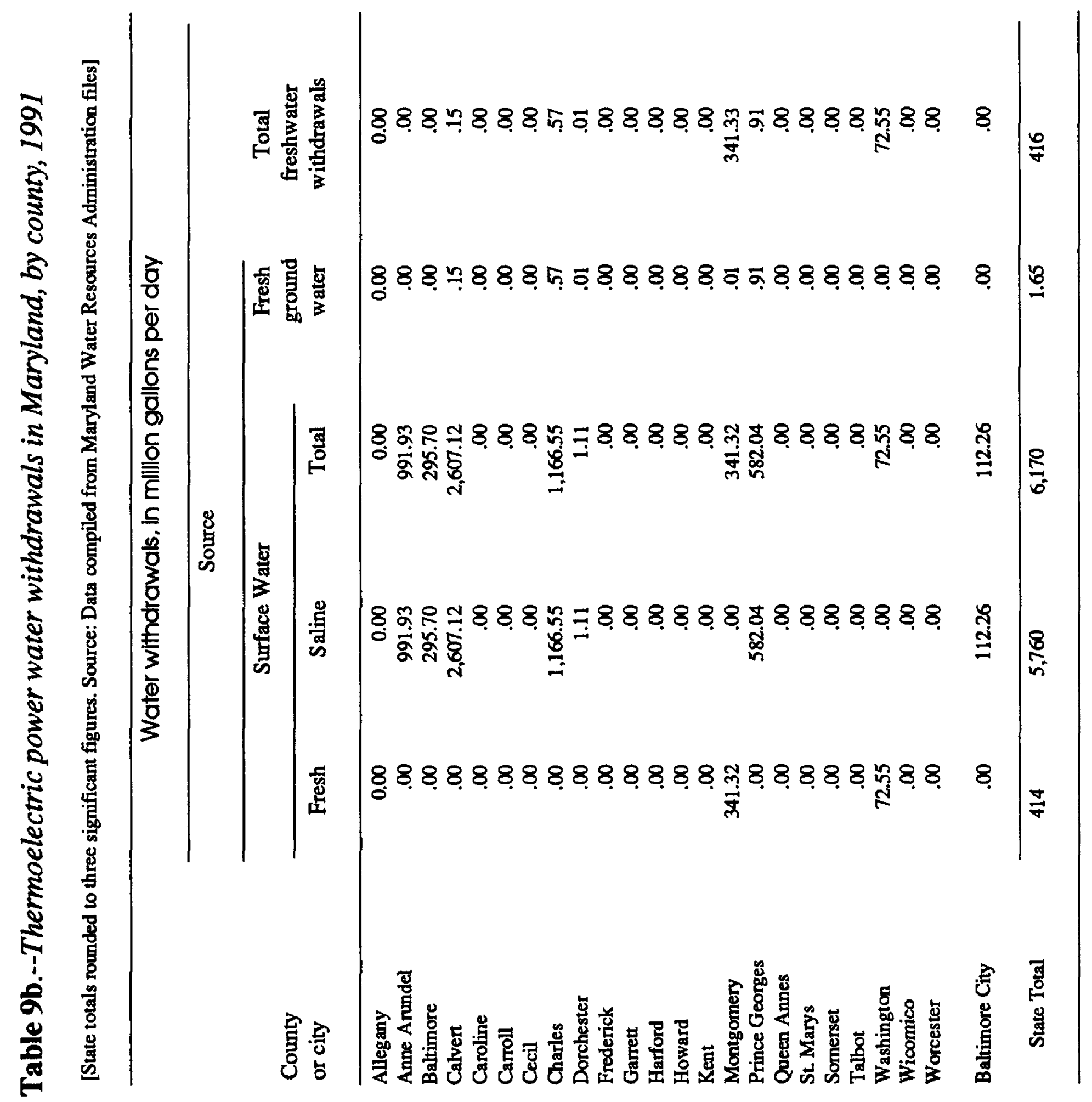


Table 10a.--Hydroelectric power water use in Maryland, by county, 1990

[State totals rounded to three significant figures. Sources: Withdrawals estimated based on annual power generation data obtained from Energy Information Administration, 1990, and Weisberg and Rose, 1985]

\begin{tabular}{|c|c|c|}
\hline \multirow[b]{2}{*}{$\begin{array}{l}\text { County } \\
\text { or } \\
\text { city }\end{array}$} & \multicolumn{2}{|c|}{ Freshwater use } \\
\hline & $\begin{array}{l}\text { Million gallons } \\
\text { per day }\end{array}$ & $\begin{array}{l}\text { Thousand } \\
\text { acre-feet } \\
\text { per year }\end{array}$ \\
\hline Allegany & 0.00 & 0.00 \\
\hline Anne Arundel & 0.00 & 0.00 \\
\hline Baltimore & 0.00 & 0.00 \\
\hline Calvert & 0.00 & 0.00 \\
\hline Caroline & 0.00 & 0.00 \\
\hline Carroll & 0.00 & 0.00 \\
\hline Cecil & 9.47 & 10.61 \\
\hline Charles & 0.00 & 0.00 \\
\hline Dorchester & 0.00 & 0.00 \\
\hline Frederick & 0.00 & 0.00 \\
\hline Garrett & 60.84 & 68.17 \\
\hline Harford & $25,616.44$ & $28,704.50$ \\
\hline Howard & 0.00 & 0.00 \\
\hline Kent & 0.00 & 0.00 \\
\hline Montgomery & 0.00 & 0.00 \\
\hline Prince Georges & 0.00 & 0.00 \\
\hline Queen Annes & 0.00 & 0.00 \\
\hline St. Marys & 0.00 & 0.00 \\
\hline Somerset & 0.00 & 0.00 \\
\hline Talbot & 0.00 & 0.00 \\
\hline Washington & 225.19 & 252.34 \\
\hline Wicomico & 0.00 & 0.00 \\
\hline Worcester & 0.00 & 0.00 \\
\hline Baltimore City & 0.00 & 0.00 \\
\hline State Total & 25,900 & 29,000 \\
\hline
\end{tabular}


Table 10b.--Hydroelectric power water use in Maryland, by county, 1991

[State totals rounded to three significant figures. Sources: Withdrawals estimated based on annual power generation data obtained from Energy Information Administration, 1991, andWeisberg and Rose, 1985]

\begin{tabular}{|c|c|c|}
\hline \multirow[b]{2}{*}{$\begin{array}{l}\text { County } \\
\text { or } \\
\text { city }\end{array}$} & \multicolumn{2}{|c|}{ Freshwater use } \\
\hline & $\begin{array}{l}\text { Million gallons } \\
\text { per day }\end{array}$ & $\begin{array}{l}\text { Thousand } \\
\text { acre-feet } \\
\text { per year }\end{array}$ \\
\hline Allegany & 0.00 & 0.00 \\
\hline Anne Arundel & .00 & .00 \\
\hline Baltimore & .00 & .00 \\
\hline Calvert & .00 & .00 \\
\hline Caroline & .00 & .00 \\
\hline Carroll & .00 & .00 \\
\hline Cecil & 8.97 & 10.06 \\
\hline Charles & .00 & .00 \\
\hline Dorchester & .00 & .00 \\
\hline Frederick & .00 & .00 \\
\hline Garrett & 60.84 & 68.20 \\
\hline Harford & $20,473.97$ & $22,951.32$ \\
\hline Howard & .00 & .00 \\
\hline Kent & .00 & .00 \\
\hline Montgomery & .00 & .00 \\
\hline Prince Georges & .00 & .00 \\
\hline Queen Annes & .00 & .00 \\
\hline St. Marys & .00 & .00 \\
\hline Somerset & .00 & .00 \\
\hline Talbot & .00 & .00 \\
\hline Washington & $1,327.00$ & $1,487.67$ \\
\hline Wicomico & .00 & .00 \\
\hline Worcester & .00 & .00 \\
\hline Baltimore City & .00 & .00 \\
\hline State Total & 21,900 & 24,500 \\
\hline
\end{tabular}


Table 11.--Livestock water withdrawals in Maryland, by county, 1990-91

[State totals rounded to three significant figures. Sources: Withdrawals estimated based on data from U.S. Department of Commerce, 1990 and U.S. Environmental Protection Agency, 1973]

Freshwater withdrawals, in million gallons per day

\begin{tabular}{|c|c|c|c|}
\hline \multirow{2}{*}{$\begin{array}{l}\text { County } \\
\text { or } \\
\text { city }\end{array}$} & \multicolumn{2}{|c|}{ Source } & \multirow{2}{*}{ Total } \\
\hline & Surface water & Ground water & \\
\hline Allegany & 0.05 & 0.02 & 0.08 \\
\hline Anne Arundel & .04 & .02 & .07 \\
\hline Baltimore & .13 & .16 & .29 \\
\hline Calvert & .02 & .00 & .02 \\
\hline Caroline & .04 & .28 & .32 \\
\hline Carroll & .31 & .46 & .77 \\
\hline Cecil & .10 & .20 & .30 \\
\hline Charles & .04 & .04 & .08 \\
\hline Dorchester & .01 & .19 & .20 \\
\hline Frederick & .48 & 1.40 & 1.88 \\
\hline Garrett & .22 & .24 & .46 \\
\hline Harford & .17 & .21 & .38 \\
\hline Howard & .10 & .08 & .18 \\
\hline Kent & .06 & .21 & .27 \\
\hline Montgomery & .11 & .14 & .25 \\
\hline Prince Georges & .04 & .02 & .06 \\
\hline Queen Annes & .06 & .22 & .28 \\
\hline St. Marys & .05 & .08 & .13 \\
\hline Somerset & .02 & .79 & .81 \\
\hline Talbot & .03 & .18 & .21 \\
\hline Washington & .31 & .71 & 1.02 \\
\hline Wicomico & .02 & 1.15 & 1.17 \\
\hline Worcester & .03 & 1.15 & 1.18 \\
\hline Baltimore City & .00 & .00 & .00 \\
\hline State Total & 2.44 & 7.95 & 10.4 \\
\hline
\end{tabular}




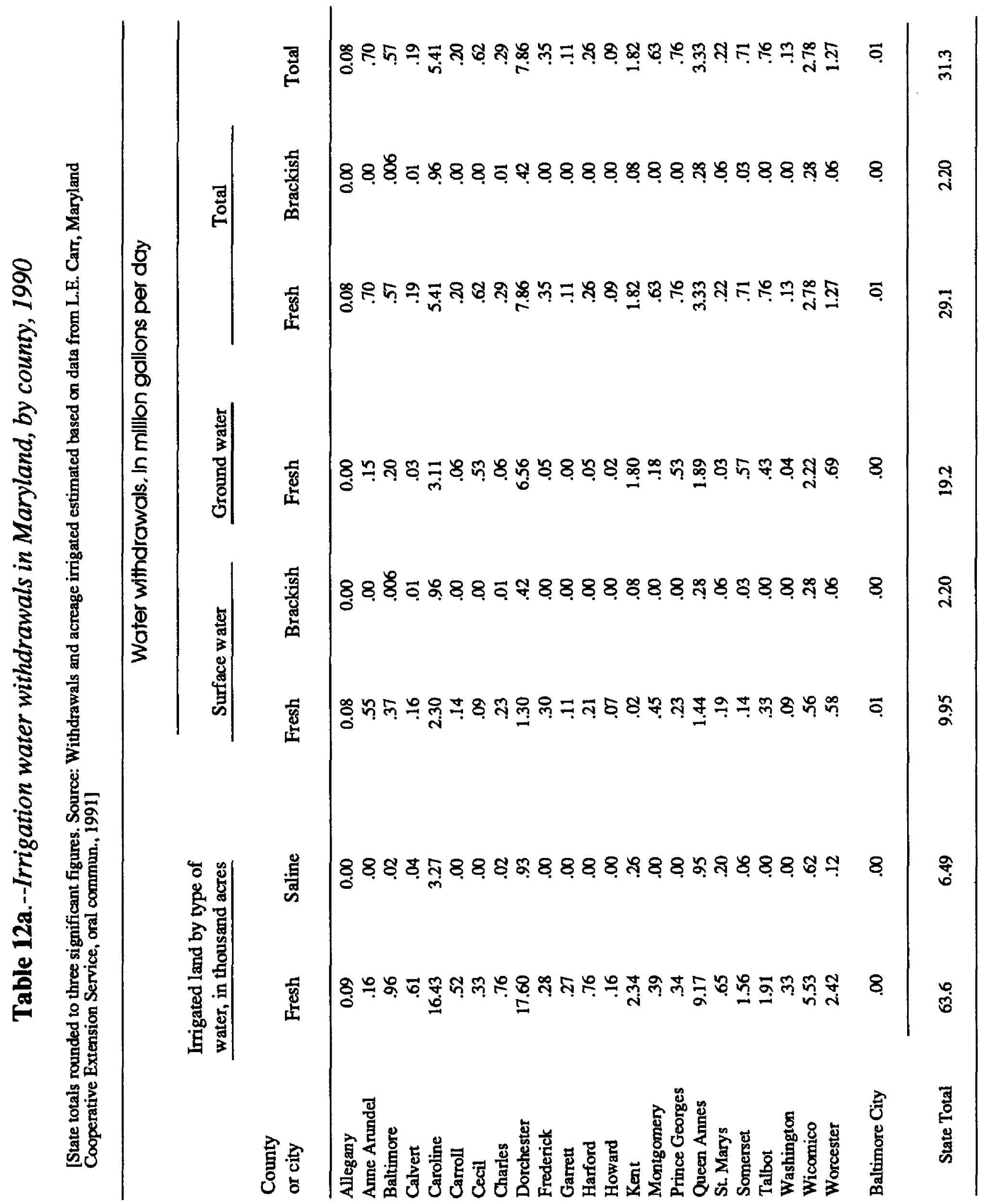




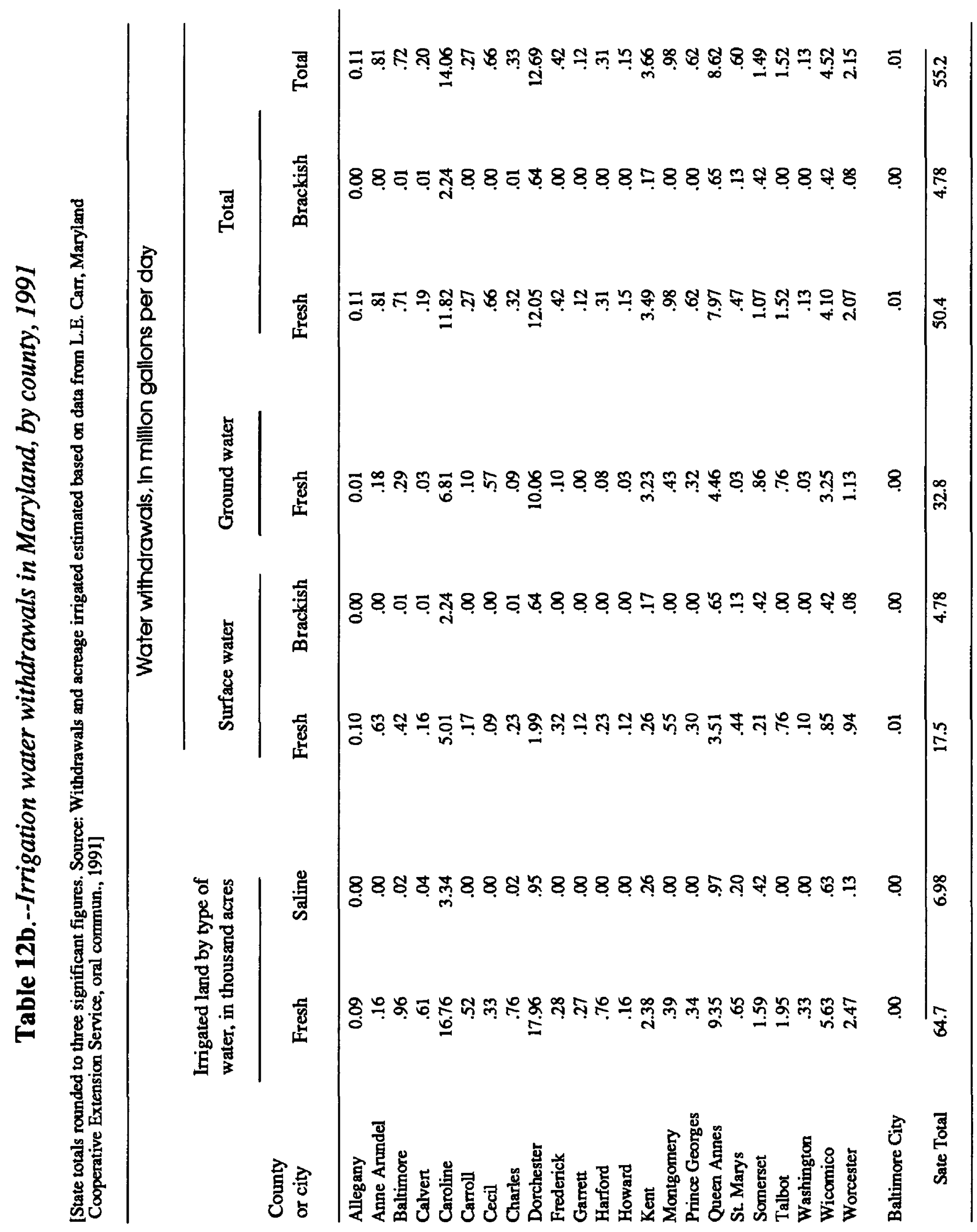




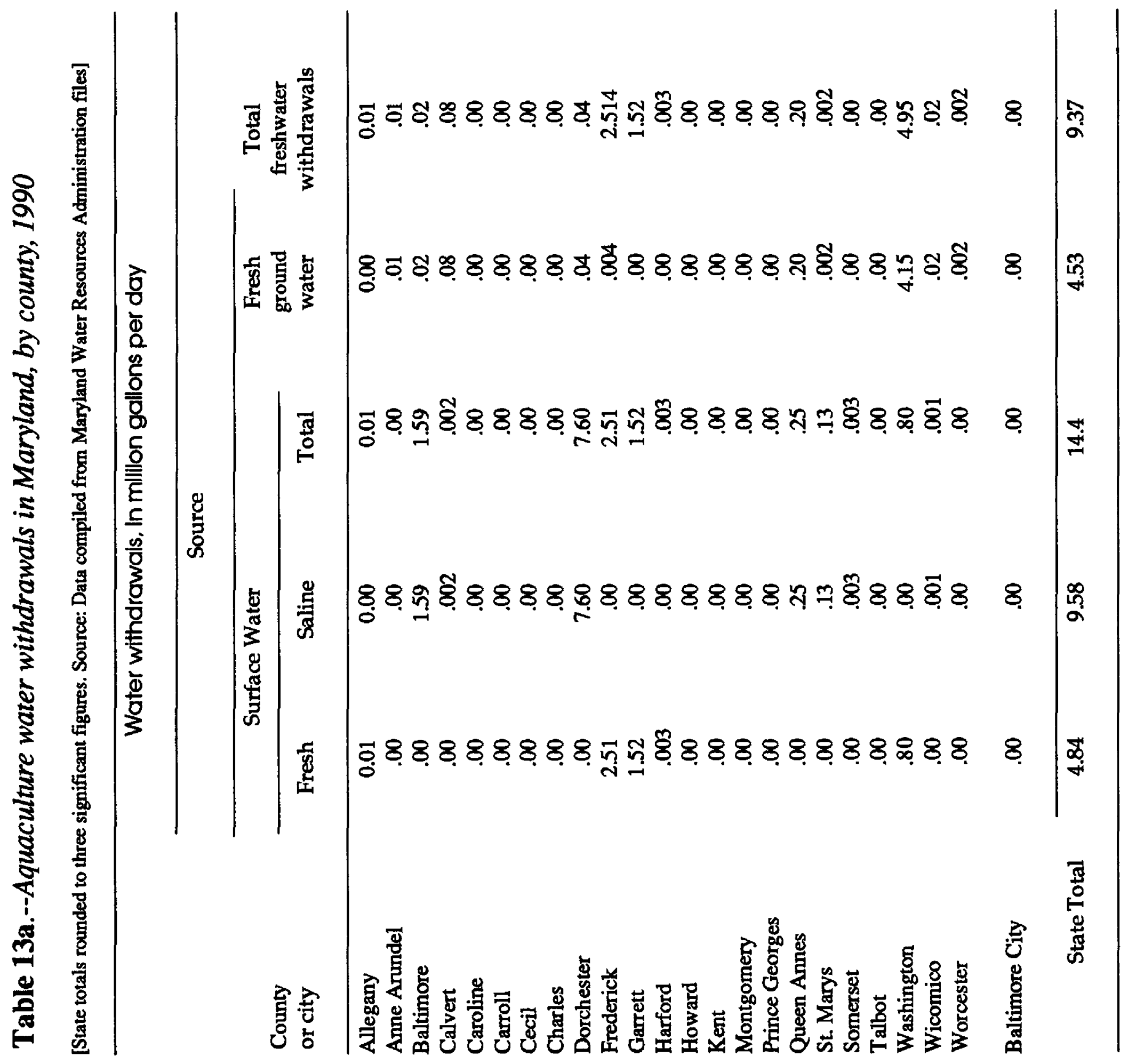




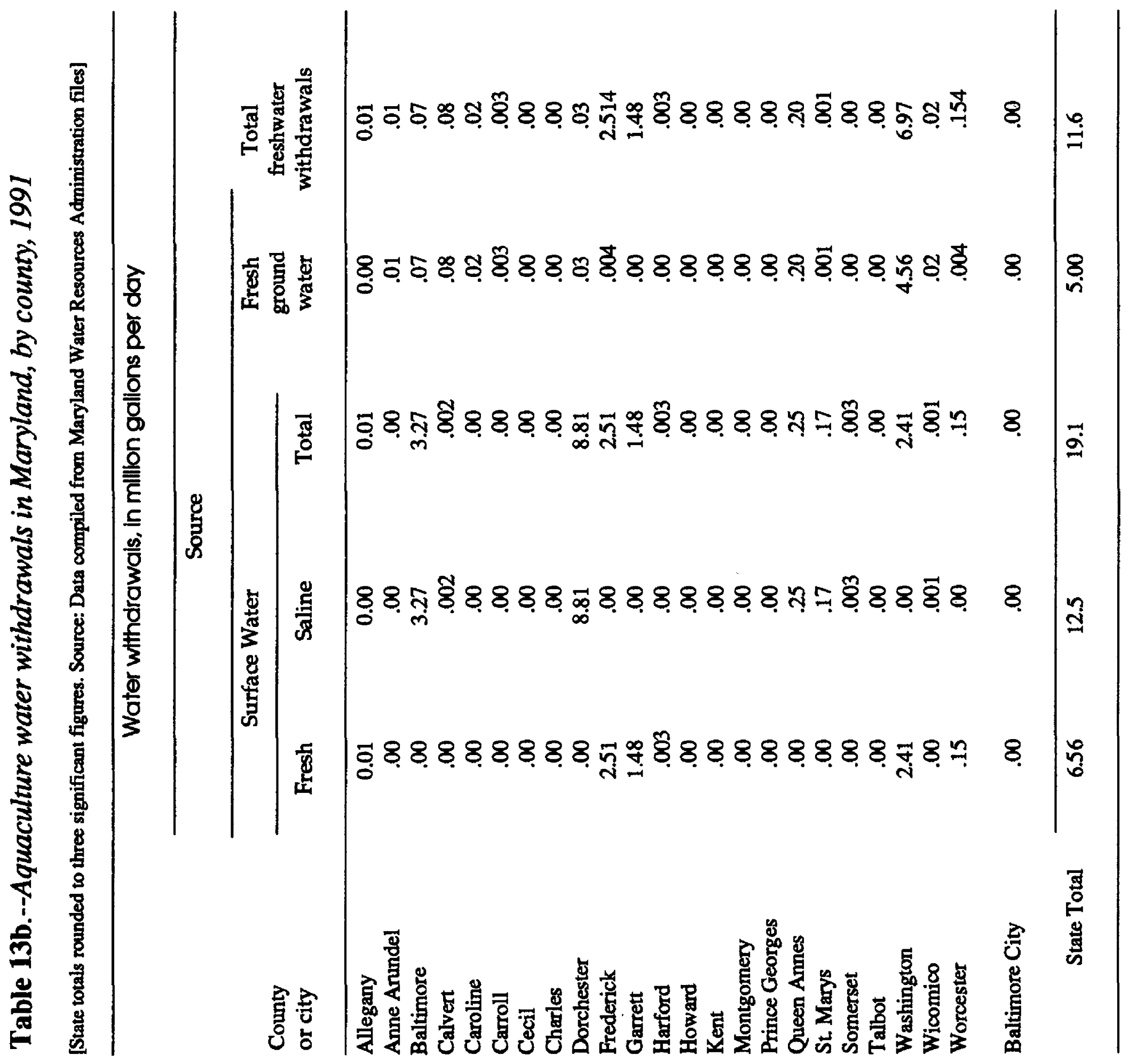

